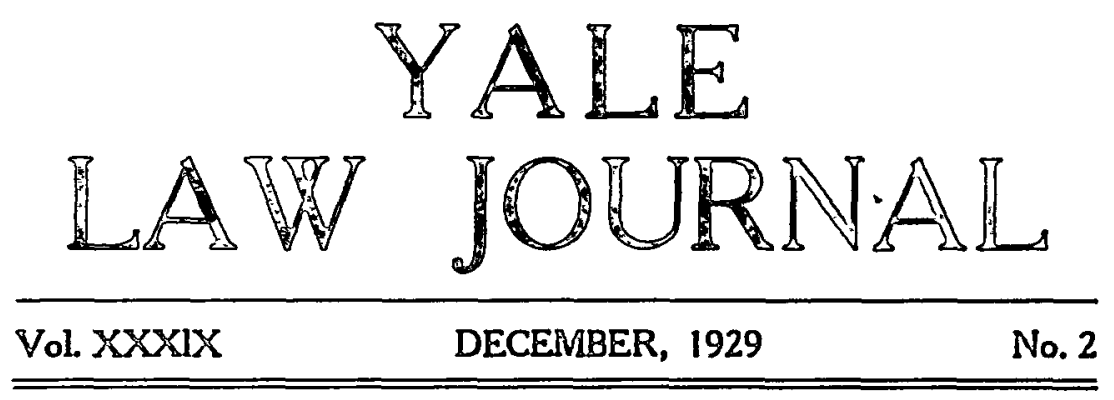

\title{
CONFISCATORY RATES AND MODERN FINANCE
}

\section{JULIUS HENRY COHEN}

What rate of return must be allowed before a publicly regulated rate is held to be confiscatory?

IIay the regulatory body in fixing the rate consider the actual result flowing from a low interest rate to bondholders and low dividend rates to preferred stocliholders?

May it consider the actual rather than the nominal return to the common stockholders?

May it consider the holding company factor in any given situation?

The recent discussion in the comprehensive prevailing and dissenting opinions in the $O^{\prime}$ Fallon case ${ }^{2}$ renews consideration of the legal theories and the technique of procedure for ascertainment of what is or is not a confiscatory rate fixed for a business devoted to a public use. How far has the United States Supreme Court committed itself? Is it true than an $8 \%$ overall return on the rate base is now guaranteed by the decisions of that court? It is undoubtedly of signal importance to both investors and consumers that the groundwork shall be carefully surveyed so that wise prognostication may be made. Already a commission in New York is at work studying the important phases of public utility regulation. What is the present state of the law on the rate of return on the rate base? This paper is confined to a limited field: A study of the United States Supreme

${ }_{1}$ St. Louis \& O'Fallon Ry. v. United States, 279 U. S. 461,49 Sup. Ct. 384 (1929). 
Court decisions with a view to determining what is likely to be the "judicial process" by which in the future the line will be drawn between confiscatory and non-confiscatory rates. To make the point of inquiry graphic, we start with the following illustrative situations:

The value of a given plant is found (under now sustainable theories of valuation for rate-making purposes) to be, we will assume, $\$ 100,000,000$. The fact-finding body finds that the outstanding bond issue at $5 \%$ is $\$ 75,000,000$; that the preferred stock is $\$ 10,000,000$, paying $61 / 2 \%$; that the current rate of return on common stock in such an enterprise is $8 \%$. Must the consumers pay a rate which, after all deductions including reserves for depreciation, ensures $8 \%$ net on the $\$ 100,000,000$, or $\$ 8,000,000$ annually?

If the return must be $8 \%$ on the $\$ 100,000,000$, then the common stockholders do not receive $8 \%$ on their property, they receive in fact $24 \%$. Deduct from $\$ 8,000,000$ the $5 \%$ payable to the $\$ 75,000,000$ bondholders, $\$ 3,750,000$, and the $61 / 2 \%$ payable to the $\$ 10,000,000$ preferred stockholders, $\$ 650,000$, a total of $\$ 4,400,000$, and there is left $\$ 3,600,000$ for $\$ 15,000,000$ common stockholders, distributable annually, or a return of $24 \%$ per annum on their property.

Assuming, however, the more normal set-up, by which, through use of the device of the holding company, the $\$ 15,000,-$ 000 of common is broken up, the interest and dividend obligation payable out of the $\$ 8,000,000$ collected from consumers will now more likely appear to be as follows:

The same $\$ 4,400,000$ is payable to bondholders and preferred stockholders of Company $A$; but the $\$ 15,000,000$ held by the common stockholders is transferred to holding company $B$, and, by exchange of stock and refinancing, Company $B$ securities are split up into $\$ 5,000,000$ of bords at $51 / 2 \%, \$ 5,000,000$ of preferred stock at $61 / 2 \%$, and $\$ 5,000,000$ of common. This requires a debt and interest service, in addition to the $\$ 4,400,000$ of Company $A$, of $\$ 275,000$ payable annually to the bondholders of $B$ and $\$ 325,000$ payable to the preferred stockholders of $B$, a total requirement of $\$ 5,000,000$-leaving a net $\$ 3,000,000$ from the $\$ 8,000,000$ revenue to be distributed to the $\$ 5,000,000$ of common, or more than $60 \%$ per annum as return on their property. ${ }^{2}$

2 That none of these figures is exaggerated is shown by the following statement of the Federal Trade Commission in SEN. Doc. No. 213, 69th Cong. 2d Sess., at 24:

"By the device of financing the holding companies quite heavily with bonds and preferred stocks at lower rates, the common-stock equities of the holding companies, ownership of which is retained by the promotors, are made to earn much higher rates.

"Certain holding-company interests for which published consolidated balance sheets and income statements are available for 1924 and 1925 
A ssuming that the original stockholders continue their holdings, and that the original cash put into the plant was not $\$ 100,000,000$, but $\$ 50,000,000$, the present $\$ 100,000,000$ value resulting from the consideration given to "going value," "reconstruction value," "good will," etc., then for the original $\$ 50,000$,000 , the annual obligations for interest and dividends would be: $5 \%$ payable to $\$ 35,000,000$ bondholders, $\$ 1,750,000$, and $61 / 2 \%$ payable to $\$ 7,500,000$ preferred stockholders, $\$ 487,500$, a total of $\$ 2,237,500$. To $\$ 7,500,000$ common stock then would be distributed the difference between the $\$ 8,000,000$ revenue and the amount payable to prior security holders, i. c., $\$ 5,762,500$, approximately $77 \%$ per annum.

Or if organized into a holding company, the $\$ 7,500,000$ common would be reduced to $\$ 1,500,000$. After payment of $5 \%, 0$ to $\$ 4,000,000$ of bondholders of the holding company and $61 / 2 \%$ to $\$ 2,000,000$ of preferred stockholders, there would be $\$ 5,432$,500 for distribution annually to $\$ 1,500,000$ of common stock, or approximately $360 \%$ per annum.

To what extent have factual situations such as these been presented to the United States Supreme Court?

(a) The Southwestern Bell Telephone Co. case. ${ }^{3}$ (Opinion of the court by McReynolds, J.) The Court calculated the base value of the property involved at $\$ 25,000,000$ and the annual net profits on operations available for depreciation and return as $\$ 2,828,617.60$, approximately $111 / 3 \%$ on $\$ 25,000,000$. On the record presented the Court sustained a finding of $6 \%$ loss per annum for depreciation. So there was left only a $51 / 3$ \% return upon "the minimum value of the property," which the Court says is too low "considering the character of the investment and interest rates then prevailing." It is clear that so far as this case goes no fixed interest return to the investor is guaranteed. On the contrary, there must be considered the interest rates then prevailing. The only testimony in the case, as appears from the record, ${ }^{\circ}$ as to what rate was needed for in-

show rates of earuings on common-stock equities, after paying interest on borrowings and diviriends on preferred stocks, ranging from 19 per cent to 55 per cent in $:: \cdot 4$ and from 21 per cent to 40 per cent in 1925. Unquestionably the $\sigma:$ Jortunity of maling such high rates of profit on the common-stock equities furnishes the primary economic motive actuating promoters of the present extensive holding-company movement in the electric power i- iustry."

3 Missouri ex: Southwestern Bell Tel. Co. v. Public Service Comm., 262 U. S. 276, 43 Sup. Ct. 544 (1923).

4 Ibid. 288, 43 Sup. Ct. at 546.

is Record, Missouri ex rel. Southwestern Bell Tel. Co. v. Public Service Comm., 568, fol. 955. 
ducing new capital to enter came from an investment banker in St. Louis, who stated that in his opinion at that time not less than $10 \%$ return was necessary to secure new capital for the company. In its argument for a rehearing the company said:

"The Court cannot ignore the fact that municipal bonds, exempted from all forms of taxation, state and national, are producing more than $6.81 \%$ upon the net proceeds of such bonds. The public press contains advertisements from day to day of industrial bonds of well-established businesses offered at a price to produce from $81 / 2 \%$ to $10 \%$, and this is the return to the investor and not the per cent which the company floating the bonds is to pay upon the amount actually received."

It was argued that there were but two ways open to the company to obtain the money needed as capital: one was by the sale of stock and the other by the sale of bonds. To reach the investor he must be assured (1) that his money is safe, (2) that his money will earn in the telephone business as much as or more than it will earn in other established lines of business in which he is able to invest. If he was offered in the locality first mortgage notes at $8 \%$, he could hardly be expected to buy telephone stock paying $6.81 \%$. By the same token, if it be shown that first lien securities sell on a basis of 5 to $51 / 2 \%$, and preferred stock in well established companies on a basis of 7 or $8 \%$, can it be argued that the stockholders are entitled to receive $10 \%$ return on all the money required, as though it were all issued for common stock?

There is nothing in the Telephome Company case, either in the majority or minority opinion, which will embarrass the Supreme Court in the slightest degree when the issue is squarely presented in making an analysis and comparison of interest and dividend rates, breaking them up as is usually done by bankers and informed investors. With strict adherence to the rule in Smyth $v$. Ames for determining value for the rate base, the Court will, it is fair to prophesy, when it comes to determining the rate, base its determination upon what the record discloses is such a net return to common stockholders as is customary and necessary to attract that kind of capital to the enterprise. This is the only return which is guaranteed by the Constitution. Brandeis, J., points out in the Telephone Company case:

"The investor agrees, by embarking capital in a utility, that its charges to the public shall be reasonable. His company is the substitute for the state in the performance of the public service; thus becoming a public servant. The compensation which the Constitution guarantees an opportunity to earn is the reasonable cost of conducting the business. Cost includes not only operating expenses, but also capital charges. Capital

\footnotetext{
SIbid. 76, fol. 145.
} 
charges cover the allowance, by way of interest, for the use of the capital, whatever the nature of the security issued therefor; the allowance for risk incurred; and enough more to attract capital. The reasonable rate to be prescribed by a commission may allow an efficiently managed utility much more. But a rate is constitutionally compensatory if it allows to the utility the opportunity to earn the cost of the service as thus defined."

Nothing in the majority opinion is contra to this. The difference between Brandeis and Holmes, JJ., and their brethren is a difference over the method to be pursued in ascertaining the base value. Nor is the following analysis by Brandeis, J., questioned:

"To decide whether a proposed rate is confiscatory, the tribunal must determine both what sum would be earned under it, and whether that sum would be a fair return. The decision involves ordinarily the making of four subsidiary ones:

"1. What the gross earnings from operating the utility under the rate in controversy would be. (A prediction)

"2. What the operating expenses and charges, while so operating, would be. (A prediction)

"3. The rate-base, that is, what the amount is upon which a return should be earned. (Under Smyth v. Ames, an opinion, largely)

"4. What rate of return should be deemed fair. (An opinion, largely)

"A decision that a rate is confiscatory (or compensatory) is thus the resultant of four subsidiary determinations. Each of the four involves forming a judgment, as distinguished from ascertaining facts. And as to each factor, there is usually room for difference in judgment. But the first two factors do not ordinarily present serious difficulties."

The difference between the judges is a difference over the method for ascertaining the value for the rate base. There is no difference over the method of ascertaining uthat is a fair retum. What is a fair return depends upon "the character of the investment and interest rates then prevailing."

How, in the face of these decisions, can a court say that common stockholders of a public utility must earn $24 \%$ or $30 \%$ or $50 \%$, or even $10 \%$ net on their property? Of course, on the basis of its past decisions, the Court will say that the common stockholder's investment today is not the actual cash he invested in the plant twenty-five years ago-if he is still the holder -but it is his aliquot share of the property at its present value. But even so, is not $24 \%$ far beyond a fair and reasonable return? Even adding a percentage for depreciation, still, if the financial set-up be studied, analyzed and properly considered before the

7 Mfissouri ex rel. Southwestern Bell Tel. Co. v. Public Service Comm. supra note 3 , at 290,43 Sup. Ct. at 547 .

8 Ibid. 291, 43 Sup. Ct. at kan 
actual dividend return is considered, it may not be $8 \%$ on the total rate base. The fundamental error in the past seems to have been to argue in terms of a lump percentage upon a lump valuation, disregarding the factor familiar to every banker and investor that when you borrow money at $5 \%$ and earn $8 \%$ with it, you are making $3 \%$ on the borrowed money and not on the plant itself. This profit on money borrowed, as distinguished from the profit on money invested, is one that so far as the writer can discover has been argued and briefed in but one case presented to the Supreme Court.9

(b) McCardle v. Indianapolis Water Co. ${ }^{10}$ In the McCardle case the Commission found that as of May 31, 1923, the value of the property used by the company was not less than $\$ 15,260$,400 ; that the annual return under existing rates would be approximately $\$ 800,000$; that $7 \%$ was a reasonable rate of return. The Commission made an order, effective January 1, 1924, prescribing a schedule increasing some of the rates.

"In its report it stated that the rates authorized might not produce a seven percent return for the immediate future; but it expressed belief that on the average over a period of approximately three years the schedule would produce an adequate return." 21

ine court below found that

"... the amount as found by the commission was less than the fair value of the property as of January 1,1924 , by more than $\$ 3,500,000$, and that 'the fair value of complainant's said property at said time was and is not less than $\$ 19,000,000$, and that the water rates imposed in that order ... are too low and are confiscatory of complainant's said property." " 12

It enjoined the enforcement of the order. The Supreme Court held, on the record in that case, "that the value of the property as of January 1,1924 , and immediately following, was not less than $\$ 19,000,000$," and affirmed the decree.

Taking a valuation of $\$ 19,000,000$ and deducting from it the funded debt of $\$ 8,231,000^{13}$ leaves in round figures a value for

\footnotetext{
- See Pacific G. \& E. Co. v. San Francisco, infra note 58.

10272 U. S. 400, 47 Sup. Ct. 144 (1926).

11 Ibid. 402, 47 Sup. Ct. at 145.

12 Ibid. 403, 47 Sup. Ct. at 146.

13 The record showed the following financial set-up of the company (Record, McCardle v. Indianapolis Water Co., 250-256, fol. 302-304):

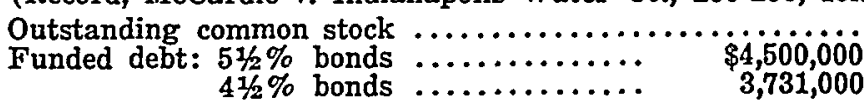

To meet the debt service required:

$\$ 5,000,000$

Interest on $51 / 2 \%$ bonds

$8,231,000$

$412 \%$ bonds 
the common stock of $\$ 10,770,000$. A net return of $\$ 515,600$ for these stockholders would be less than 5.5\%. An exhibit in the case showed that on the company's base valuation of \$18,641,000 the return on the whole investment would be less than 5.1\%.14 Judge Geiger below concluded his opinion by saying:

"I am not confronted with the problem of fixing a valuation within the range of dispute upon spot reproduction ... because the complainant comes into this Court and offers to accept \$̧19,000,000 as a fair basis of valuation, even though, as it says, and I think has reason to say, and could support it, it could, upon the record, sustain a higher valuation. That will be the finding, and it follows, I think without dispute-without the possibility of serious dispute-that, that being so, the rates or the tariffs or charges that have been promulgated by the respondent Commission, no matter what figure of measuring it, what rate of measuring it, we adopt, provided it be above five per cent, that schedule will not satisfy the constitutional requirements of the plaintiff in this case. ..." 15

It appears clearly that neither the Commission nor the Supreme Court was called upon to pass upon the question we raised at the outset of this paper. However, in the various opinions of the Court are found statements which do have important bearing upon that question. In speaking of the value of the property which was to be taken as the rate base, the Court referred to the then high level of prices and wages, and said:

"And we may take judicial notice of the fact that there has been no substantial general decline in the prices of labor and materials since that time. The trend has been upuard rother than downward." 16

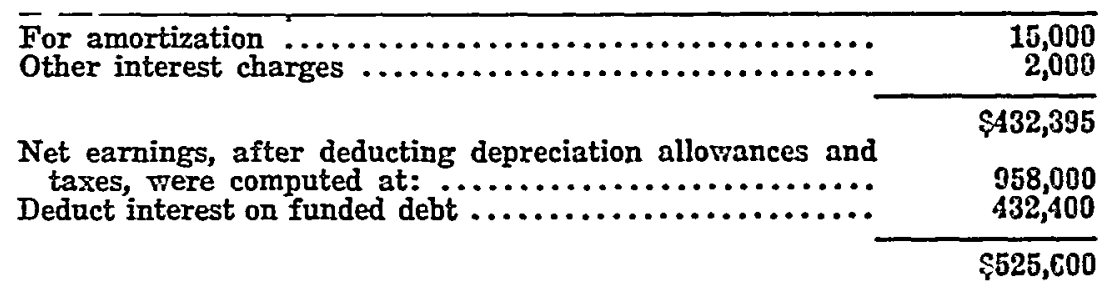

11 Record, 255, fol. 304. It did appear in the case that of the company's outstanding stock and bonds $\$ 4,500,000$ of common stocls and $\$ 3,000,000$ of bonds were issued as dividends to common stockholders (Record 283-292, 327 , fol. 337-342, 381); but in view of the fact that the Commission itself had ignored that fact and eleven months pricr to the finding under review had held the property to be worth $\$ 16,450,000$ for purposes of authorizing a new bond issue, even if this huge increment to common stocliholders influenced the Commission in fixing the rate base, it did not influence the court below (see opinion, Record 106-9, fol. 61-2) and the Supreme Court upheld the court below.

15 Record 64, fol. 112.

16 McCardle v. Indianapolis Water Co., supra note 10, at 112, 17 Sup. Ct. at 149 [Italics ours]. 
The majority of the Court (per Butler, J.) said:

"It is obvious that rates of yield on investments in bonds plus brokerage is substantially less than the rate of return required to constitute just compensation for the use of properties in the public service. Bonds rarely constitute the source of all the money required to finance public utilities. And investors insist on higher yields on stock than current rates of interest on bonds. Obviously, the cost of money to finance the whole enterprise is not measured by interest rates plus brokerage on bonds floated for only a part of the investment." 17

It is clear from this that, when the facts are properly presented, neither the majority nor minority of the Court will refuse to consider facts which establish in a given case that the enterprise can be financed on less than an average of $7 \%$.

Elsewhere in the opinion, Mr. Justice Butler said:

"But in determining present value, consideration must be given to prices and wages prevailing at the time of the investigation; and, in the light of all the circumstances, there must be an honest and intelligent forecast as to probable price and wage levels during a reasonable period in the immediate future." 18

To do this is, of course, difficult. If railroad and interstate commerce commissions could make such prophecies with ac-

17 Ibid. 419,47 Sup. Ct. at 151.

${ }^{18}$ Ibid. 408,47 Sup. Ct. at 147 [Italics ours].

The method by which the Court approaches the problem of determining present value is indicated as follows:

"It is well established that values of utility properties fluctuate, and that owners must bear the decline and are entitled to the increase. The decision of this court in Smyth v. Ames, $169 \mathrm{U}$. S. 466, 547, declares that to ascertain value 'the present as compared with the original cost of construction' are, among other things, matters for consideration. But this does not mean that the original cost or the present cost or some figure arbitrarily chosen between these two is to be taken as the measure. The weight to be given to such cost figures and other items or classes of evidenco is to be determined in the light of the facts of the case in hand. By far the greater part of the company's land and plant was acquired and constructed long before the war. The present value of the land is much greater than its cost; and the present cost of construction of those parts of the plant is much more than their reasonable original cost. In fact, prices and values have so changed that the amount paid for land in the early years of the enterprise and the cost of plant elements constructed prior to the great rise of prices due to the war do not constitute any real indication of their value at the present time [citing cases]. Undoubtedly, the reasonable cost of a system of waterworks, well-planned and efficient for the public service, is good evidence of its value at the time of construction. And such actual cost will continue fairly well to measure the amount to be attributed to the physical elements of the property so long as there is no change in the level of applicable prices. And, as indicated by the report of the commission, it is true that, if the tendency or trend of prices is not definitely upward or downward and it does not nppear probable that there will be a substantial change of prices, then the present value of lands plus the present cost of constructing the plant, less depreciation, if any, is a fair measure of the value of the physical elements of the property." Ibid. 410,47 Sup. Ct. at 148 [Italics ours]. 
curacy, then, indeed, their opinions would furnish a most profitable base for stock investors. But it is not "accuracy of forecast" which is required but a reasonable look ahead, based upon the evidence submitted.20

The method employed is equally applicable to the consideration of interest and dividend rates. The utterances of both the majority and minority of the Court would scarcely leave room for any doubt that upon a properly presented case (such as we illustrated at the beginning of this paper) the Court would adopt the same method for determining the rates to be charged by utility companies to consumers.

Such facts as have been recently developed by the Federal Trade Commission and such examples as we have given of dividend returns to those who hold common stock as compared with interest returns have not as yet been brought before the Supreme Court for consideration. We may be sure that investors will be allowed a return on a rate base which includes such increases in value of the property used as may be shown by the record. They will, therefore, participate in the general rise of price levels or real estate values; but by the same token they take the risk, as the Court has frequently pointed out, of a drop in values.

The "prudent investment theory" has failed to incorporate itself into the law of the land. ${ }^{20}$ When prices are sky-rocketing, the consumer will pay high rates. When price levels go down, the investor will lose his high return. There is no certainty either way, argues Mir. Justice Brandeis, though, as he says, reasonable certainty is most needed. But even when prices are on a high level, must the consumer pay rates which will return dividends to common stockholders in well established utilities as high as $20,30,40,50$ and even $150 \%$ ? So far as we have been able to discover, there is no constitutional provision and neither Supreme Court decision nor dictum which guarantees the common stockholder any such return.

(c) Bluefield Water Works case.21 The opinion of the Court here, as in the Southwestern Bell Telephone Co. case, is by

18 "In every confiscation case, the future, as well as the present must bs regarded. It must be determined whether the rates complained of are yielding and will yield, over and above the amounts required to pay tases and proper operating charges, a sum sufficient to constitute just compeneation for the use of the property employed to furnish the servico; that is, a reasonable rate of return on the value of the property at the time of tho investigation and for a reasonable time in the immediate future." Ibid. 408, 47 Sup. Ct. at 148 [Italics ours].

20 See Brandeis, dissenting, in Southwestern Bell Telephone crse, oupra note 3 , at $310,311,43$ Sup. Ct. at 554 .

21 Bluefield Water Works \& Improv. Co. v. Public Service Comm., 262 U. S. 679, 43 Sup. Ct. 675 (1923). 
Butler, J. (Brandeis, J., concurring for the reasons stated by him in the Southwestern Bell Telephone Co. case). The rule is stated as follows:

"What annual rate will constitute just compensation depends upon many circumstances and must be determined by the exercise of a fair and enlightened judgment, having regard to all relevant facts. A public utility is entitled to such rates as will permit it to earn a return on the value of the property which it employs for the convenience of the public equal to that generally being made at the same time and in the same general part of the country on investments in other business undertakings which are attended by corresponding risks and uncertainties; but it has no constitutional right to profits such as are realized or anticipated in highly profitable enterprises or speculative ventures. The return should be reasonably sufficient to assure confidence in the financial soundness of the utility, and should be adequate, under efficient and economical management, to maintain and support its credit and enable it to raise the money necessary for the proper discharge of its public duties. A rate of return may be reasonable at one time, and become too high or too low by changes affecting opportunities for investment, the money market and business conditions generally." 22

This rule is deduced from an analysis of previous cases which portend clearly, it would seem, that, when presented, the Court will not ignore the financial set-up of the company, together with such evidence as will establish the then market rates upon which capital may be secured. ${ }^{23}$ The Court will consider the

22 Ibid. 692, 43 Sup. Ct. at 679.

${ }^{23}$ See ibid. 693-4, 43 Sup. Ct. at 679 . The Court cited Willcox v. Consolidated Gas Co., infra note 25 , in which it had

"... held that the question whether a rate yields such a return as not to be confiscatory depends upon circumstances, locality and risk, and that no proper rate can be established for all cases; and that, under the circumstances of that case, 6 per cent was a fair return on the value of the property employed in supplying gas to the city of New York, and that a rate yielding that return was not confiscatory. In that case the investment was held to be safe, returns certain and risk reduced almost to a minimum-as nearly a safe and secure investment as could be imagined in regard to any private manufacturing enterprise."

It referred to its decision in the Cedar Rapids case (Cedar Rapids Gas Co. v. Cedar Rapids, 223 U. S. 655, 32 Sup. Ct. 389 (1912)) :

"This Court declined to reverse the state court where the value of tho plant considerably exceeded its cost, and the estimated return was over 6 per cent.

"In 1915, in Des Moines Gas Co. v. Des Moines, 238 U. S. 153, 172, 36 Sup. Ct. 811, this court declined to reverse the United States district court in refusing an injunction upon the conclusion reached that a return of 6 per cent per annum upon the value would not be confiscatory.

"In 1919, this court, in Lincoln Gas \& E. L. Co. v. Lincoln, 250 U. S. $256,268,39$ Sup. Ct. 454 , declined on the facts of that case to approve a finding that no rate yielding as much as 6 per cent on the invested capital could be regarded as confiscatory."

Referring to Minneapolis v. Rand, 285 Fed. 818 (C. C. A. 8th, 1923) the Court said:

"The Circuit Court of Appeals of the Eighth Circuit sustained, as against the attack of the city on the ground that it was excessive, $7 / 6$ per' cont. 
ability of the company to borrow money on low rates of interest or to raise capital on low dividend rates. It will, as it has repeatedly said, consider the factual situation in each case. A new, untried company may be entitled to higher rates because it must pay more for its money than one solidly established. But it may be observed that if the rates of solidly established companies are sufficiently low, new companies will not be able to charge high rates in competition.

The Court found from the record in the case that:

"... the rate of return has been low through a long period up to the time of the inquiry by the commission here involved. For example, the average rate of return on the total cost of the property from 1895 to 1915 , inclusive, was less than 5 per cent; from 1911 to 1915 , inclusive, about 4.4 per cent, without allowance for depreciation. In 1919, the net operating income was approximately $\$ 24,700$, leaving $\$ 15,500$, approximately, or 3.4 per cent on $\$ 460,000$ fixed by the commission, after deducting 2 per cent for depreciation. In 1920, the net operating income was approximately $\$ 25,465$, leaving $\$ 16,265$ for return, after allowing for depreciation. Under the facts and circumstances indicated by the record, we think that a rate of return of 6 per cent upon the value of the property is substantially too low to constitute just compensation for the use of the property employed to render the service." 24

The Commission fixed $\$ 460,000$ as the base valuation. It found that under existing rates, assuming some increase of business, gross earnings in 1921 wrui.ld be $\$ 80,000$ and operating expenses $\$ 53,000$, leaving $\$ 27,000$. the equivalent of $5.87 \%$, or $3.87 \%$ after deducting $2 \%$ all $\cdots$.ed for depreciation. It held existing rates insufficient to the : rtent of $\$ 10,000$. It allowed the company an increase of $16 \%$ on $80 \%$ of its bills, a net increase of about $12.8 \%$ or $\$ 10,210$. Its order was sustained by the Supreme Court of Appeals of West Virginia. The United States Supreme Court reversed the lower court. Adding $\$ 10,240$ to a net of $\$ 27,000$ would give the company $\$ 37,240$ on $\$ 460,000-a$ too low valuation. As the United States Supreme Court was not called upon to pass upon an increased valuation, it did not go into the capital set-up of the company. Nothing whatever is said upon this phase of the matter. The whole discussion turns upon the proper rule to be applied for ascertaining the value for basing the rate, $i . e_{\text {., }}$ the rate base.

The court below had held that it could not review the finding of facts of the Commission. But the Supreme Court held that

found by a special master and approved by the district court as a fair and reasonable return on the capital investment-the value of the property."

2 Bluefield Water Works \& Improv. Co. v. Public Service Comm., supra note 21 , at 695,43 'Sup. Ct. at 679 . 
this was error because the record clearly showed that the Commission, in arriving at its final figure, did not accord proper, if any, weight to the greatly enhanced cost of construction.

(d) Willcox v. Consolidated Gas Co. ${ }^{25}$ In 1906, the Legislature of New York passed the Eighty Cent Gas Law. An eighty cent rate was found to yield $6 \%$. On application for an injunction to restrain enforcement of the rate upon the ground that it was confiscatory, the court below granted the injunction. The Supreme Court reversed the court below and held the statute constitutional. Such utterances as are made in the case are all favorable to the opinions expressed in this article.

"The evidence shows that from their creation, down to the consolidation in 1884, these companies had been free from legislative regulation upon the amount of the rates to be charged for gas. They had been most prosperous and had divided very large earnings in the shape of dividends to their stockholders, dividends which are characterized by the Senate committee, appointed in 1885 to investigate the facts surrounding the consolidation, as enormous. The report of that committee shows that several of the companies had averaged, from their creation, dividends over 16 per cent, and the six companies in the year 1884 paid a dividend upon capital which had been increased by earnings, as in the case of the Manhattan and the New York, of 18 per cent; and, had it been upon the money actually paid in, it would have been nearly 25 per cent." ${ }^{20}$

The court below found the value of the tangible assets actually employed at the time of the commencement of the company's suit in the business of supplying gas to be $\$ 47,831,435$, to which it added $\$ 12,000,000$ as the value of the company's franchise. The Supreme Court disallowed this $\$ 12,000,000$. Altering the finding of the court below as to the rate base by allowing a franchise valuation of but $\$ 7,781,000$, the Court fixed the total valuation for rate making at $\$ 55,612,435$, upon which $6 \%$ would be $\$ 3,336,746.10$. On an eighty cent rate the Court figured a return of $\$ 3,024,592.14$, "which is nearly $51 / 2$ per cent on the above total of $\$ 55,612,435 . "$. 27

But what is the rule for determining the rate of return to investors in fixing the rates to be charged to consumers? Peckham, J., writes for the entire court:

"There is no particular rate of compensation which must in all cases and in all parts of the country be regarded as sufficient for capital invested in business enterprises." 28

${ }^{25} 212$ U. S. 19, 29 Sup. Ct. 192 (1909). Opinion of the Court by Peckham, J. All concurred.

26 Ibid. 45, 29 Sup. Ct. at 197.

27 Ibid. 48, 29 Sup. Ct. at 198.

$28 \mathrm{Ibid}$. 
How are we to find the proper rate?

"Such compensation must depend greatly upon circumstances and locality; among other things, the amount of risk in the business is a most important factor, as well as the locality where the business is conducted and the rate expected and usually realized there upon investments of a somewhat similar nature with regard to the risk attending them. ... The less risk, the less right to any unusual returns upon the investments. One who invests his money in a business of a somewhat hazardous character is very properly held to have the right to a larger return without legislative interference than can be obtained from an investment in government bonds or other perfectly safe security. The man that invested in gas stock in 1823 had a right to look for and obtain, if possible, a much greater rate upon his investment than he who invested in such property in the city of New York years after the risk and danger involved had been almost entirely eliminated.

"In an investment in a gas company, such as complainant's, the risk is reduced almost to a minimum. It is a corporation, which in fact, as the court below remarks, monopolizes the gas service of the largest city in America, and is secure against competition under the circumstances in which it is placed, because it is a proposition almost unthinliable that the city of New York would, for purposes of making competition, permit the streets of the city to be again torn up in order to allow the mains of another company to be laid all through them to supply gas which the present company can adequately supply. And, so far as it is given us to look into the future, it seems as certain as anything of such a nature can be, that the demand for gas will increase, and, at the reduced price, increase to a considerable extent. An interest in such a business is as near a safe and secure investment as can be imagined with regard to any private manufacturing business, although it is recognized at the same time that there is a possible element of risk, even in such a business. ... Under the circumstances, the court [below] held that a rate which would permit a return of 6 per cent would be enough to avoid the charge of confiscation, and for the reason that a return of such an amount was the return ordinarily sought and obtained on investments of that degree of safety in the city of New York." ${ }^{20}$

The testimony of experts for the appellants, while indicating that in their opinion a return of $6 \%$ was liberal, gave it also as their opinion that the company would not have "the slightest difficulty in floating at par all the five per cent bonds and all the stock bearing six per cent dividends" that might be required for new construction..$^{30}$ On this record, the Supreme Court was fully justified in its conclusions. Here again, as in the three preceding cases, the real issue in the case presented to the Supreme Court concerned the matter of valuation and not the determination of the interest return.

28 Ibid.

30 Record, Tr:11rox v. Consolifiated Gas Co., at 2350. 
(e) Galveston Electric Co. v. Galveston. ${ }^{31}$ This case is cited by counsel for the water company in the McCardle case as supporting generally an $8 \%$ return on the rate base. The case did not so hold. It involved the five cent fare on the street railway system of Galveston. The suit was brought to enjoin the fare, it being claimed by the company that it was confiscatory. The City of Galveston claimed that the rate was sufficient to yield the company an $8 \%$ return on the value of the property used in the public service. The court below refused an injunction. The Supreme Court sustained the court below, Brandeis, J., delivering the opinion of the Court. All that the Court said on the $8 \%$ return was this:

"It is thus clear that, both in the year ending June 30, 1920, and in the calendar year 1920, the net earnings of the system were less than 8 per cent of its value, whether the value be estimated on the basis of prudent investment or on the basis of the reproduction cost actually adopted. When the court rendered its decision the ordinance had been tested for more than a year and a half-a period ample in ordinary times to test the current effect of the rate prescribed and to indicate its probable effect in the near future. The times here involved were, however, in a high degree abnormal. It did not follow that, because the system had earned less than 8 per cent in 1919 and in 1920, it would earn less than 8 per cent in $1921^{32}$... [The District Judge's] determination whether the prescribed rate would be confiscatory was necessarily based largely on a prophecy, for normal conditions had not been restored. He found that gross revenues were steadily increasing; and that they were larger under the 5 -cent fare than they had been during the preceding year when the 6-cent rate was in effect. He was convinced that operating costs would decrease largely during the year. His two opinions show that every element upon which his prophecy should be based received careful consideration. We cannot say that the evidence compelled a conviction that the rate would prove inadequate." ${ }^{33}$

Again :

"We know judicially that the period has, in general, been one of continuous price recession, and that the current rates of return on capital are much lower than they then were. But we cannot know to what extent the important changes occurring have affected either gross revenues or the net return." 34

(f) Lincoln Gas Co.v. Lincoln.35 This is another case cited by counsel for the company in the McCardle case to support a general rate return of $8 \%$. The case involved the Lincoln, Neb-

31258 U. S. 388, 42 Sup. Ct. 351 (1922).

32 Ibid. 400, 42 Sup. Ct. at 356.

33 Ibid. 401, 42 Sup. Ct. at 357.

34 Ibid. 402, 42 Sup. Ct. at 357.

35250 U. S. 256, 39 Sup. Ct. 454 (1919). 
raska, one dollar gas rate ordinance, which the company claimed

- was confiscatory. It brought a bill to restrain enforcement of the ordinance. Upon final hearing, the court dismissed the bill. The Supreme Court affirmed this decision, Pitney, J., on this occasion writing the opinion of the Court. All that the Supreme Court felt called upon to say with reference to the interest return below which rates would be found to be confiscatory was the following:

"We cannot approve the finding that no rate yielding as much as $6 \mathrm{per}$ cent upon the invested capital could be regarded as confiscatory, in view of the undisputed evidence, accepted by the master, that 8 per cent was the lowest rate sought and generally obtained as a return upon the capital invested in banking, merchandising and other business in the vicinity; 7 per cent being the 'legal rate' of interest in Nebraska. Complainant had not such a monopoly nor were its profits 'virtually guaranteed' in such a sense as to permit the public authorities to restrict it to a return of 6 per cent upon its invested capital. It is not entirely clear, however, that the rate ordinance did so restrict it." so

(g) In Smyth v. Ames, ${ }^{37} \mathrm{Mr}$. James C. Carter reviewed the status of the decisions up to that time (1897). His review indicated that prior to that time no occasion had as yet arisen for such an analysis by the Supreme Court as we have here suggested. Up to 1904 there had been no intimation from the Court in terms of interest return of how the Court applied the rule of "unreasonable" return. But in 1904. When interest returns were notoriously low and it then appeared to the Supreme Court that much of the capital in a company was invested twenty and thirty years before, Mr. Justice Peckham could take judicial notice of prevailing investment returns and could say, in the Stanislaus $:$ se, for the whole Court:

"To be a jle still to realize 6 per cent upon the money originally invested is more than most people are able to accomplish in any ordinary investment, and more than is necessary in order to give just compensation for property at the time it is used for the public purpose originally intended." $s \mathrm{~s}$

In 1909, the Court again took judicial notice of the prevailing interest rates and said (per Moody, J.) in the Knoxville case:

"Upon any aspect of the evidence the company is certain to obtain a substantial net revenue under the operation of the ordinance. The net income, in any event, would be substantially 6

36 Ibid. 267,39 Sup. Ct. at 457 .

37169 U. S. $466,514,515$ (1898).

s8 Stanislaus County v. San Joaquin \& II. R. Canal \& I. Co., 192 U. S. 201, 216, 24 Sup. Ct. 211, 247 (1904). 
per cent, or 4 per cent after an allowance of 2 per cent for depreciation." 30

(h) Newton $v$. Consolidated Gas Co.40 The earlier case of Willcox $v$. Consolidated Gas Co:41 dealt with the 1906 eighty cent gas law over the period of 1906 to 1908, at which time a $6 \%$ rate return was held to be adequate. Newton $v$. Consolidated Gas Co. dealt with the same eighty cent gas law, but on the basis of conditions for the eight months preceding January 1, 1919. The Supreme Court took judicial notice "of the enormous increase in cost of labor and materials since this court declared that appellee might possibly earn 6 per centum under the 80cent rate." The master found, as to the results of actual operations during all of 1918 and the first eight months of 1919, that:

"On the basis of the prices, rates of pay, and costs prevailing during the eight months beginning January 1, 1919, the cost of making and distributing gas has been such as to allow a very small, if any, return, on even the actual investment; and since September 1, 1919, the cost of making and distributing gas has been increased in a number of respects so that the fair inference is that the complainant company now finds itself without any return upon the investment." 42

This portion of the master's finding of fact was adopted by the Supreme Court, all concurring, Mrr. Justice McReynolds writing the opinion, and Mr. Justice Clarke concurring in the result. By way of caution, the Court said at the end of its opinion:

"It seems proper to add that we do not intend by anything said herein to intimate what would have been a reasonable rate for the sale of gas under the circumstances disclosed." 13

In short, the decision of the Supreme Court is that, on the basis of the record, the eighty cent gas act was unconstitutional as applied to the Consolidated Gas Company. Nothing is said in the decision about $8 \%$ or any other per centum. Obviously, since the Court had found that, on the basis of eighty cents the company could not even earn any return on its actual investment, it was not necessary to the case to do more than to hold that the act was confiscatory.

In the court below, however, it was said by Learned Hand, J.:

"The evidence in this record indicates that 8 per cent. is the going rate at the present time, and that stands uncontradicted.

${ }^{39}$ Knoxville v. Knoxville Water Co., 212 U. S. 1, 17, 29 Sup. Ct. 148, 154 (1909).

40258 U. S. 165,42 Sup. Ct. 264 (1922).

41 Supra note 25.

42 Supra note 40, at 171, 42 Sup. Ct. at 265.

13 Ibid. 178, 42 Sup. Ct. at 268. 
For many months past the United States, certainly the most solvent debtor in the world, has paid either 6 or nearly 6 per cent., and other governments higher. As the facts develop in this case, I need not find any rate, except to say that less than 6 per cent. would be insuificient. I have made findings based upon both 6 per cent. and 7 per cent." ss

In passing, Hand, J., made the following observations:

"If the rate is to correspond with the market, 7 per cent. would scarcely seem too high, and at least so much appears to have been taken as the standard in Lincoln v. Lincoln Gas Co., supra, the last declaration of the court." 45

Examination of the decision in the Lincoln case makes it clear that, precisely as it had done with the eighty cent gas law, the United States Supreme Court confined its decision to the facts in the case before it. It did not intend to make $7 \%$ a standard. In an earlier sentence Hand, J., seems to have accurately apprehended the meaning of the decision in the Lincoln case. He said:

"In Lincaln v. Lincaln Gas Co., 250 U. S. 256, 39 Sup. Ct. 454, the court indicated that changed conditions of investment might change the rate. Eight per cent. was mentioned, though probably not as intended to cover the case of a sure monopoly such as this was described to be in Willcox v. Con. Gas Co."

The actual situation as Hand, J., found it in the case before him, was that taking the "tangibles" alone and valuing them not on the estimate of experts, but on their cost, except in the case of the land,

".. . the company will not much more than earn upon them 5 per cent. on the basis of 1918 costs, or $3 \frac{1}{6}$ per cent. on the basis of 1919 costs. If the franchises are added, the earnings will be $41 / 2$ per cent. on the basis of 1918 costs and 3 per cent. on that of 1919. As the 1919 prices have now obtained for over a

13 Consolidated Gas Co. of N. Y. V. Newton, 267 Fed. 231, 241 (S. D. N. Y. 1920). [Italies ours] Under the hesding of "Reasonable Rate of Return" the master had reported:

"Since the decision of the prior suit in 1909 (Willcox v. Consolidated Gas Co., 212 U. S. 19) there has been a radical change in business conditions. The investment market of the vorld is on an entirely difierent basis than that under consideration by the court in 1909. Taling into consideration all the factors which the courts have indicatcd as entering into the determination of a reasonable and proper return upon capital employed in supplying gas to the public, I am of opinion that this complainant company is entitled to receive a return of at least 8 per cent. on the value of the property used in its gas business." Record, at 62 . It will be observed that this finding by the master was not supported by the District Court nor by the United States Supreme Court, nor vas it necessary at all to the decision.

\$s Consolidated Gas Co. of N. Y. v. Newton, supra note 41, at 242.

16 Ibid. 241. 
year and a half, it is fair to say that, in a long enough future to call for some relief, the company cannot earn more than $31 / 4$ per cent. on its 'tangibles' alone." 47

Based on competent expert testimony, the court doubted very much if the company could earn more than $11 / 2 \%$ on the tangibles alone.

(i) In a footnote to his opinion in the Southwestern Bell Telephone Co. case, ${ }^{48}$ Brandeis, J., calls attention to the fact that since Smyth v. Ames the Supreme Court had up to 1922 dealt with the validity (under the Fourteenth Amendment) of rate regulation by the states in over fifty cases. Yet in only twentyfive of these did the Court, he pointed out, pass upon the question of whether a rate fixed or approved by a state commission denied to the utility the opportunity of earning a fair return upon the fair value of the property. In none of these twentyfive cases had an order of a state commission, made after a full hearing, been declared void by the Supreme Court, on the ground that the finding of the rate base or value was too low. In none - of them was the order declared void on the ground that the commission fixed too low a percentage of return. He points out further that though lower federal courts and state courts could have occasionally intervened with effect, the instances were relatively few as compared with the number of adverse decisions of the commissions, and that even where orders fixing rates had been set aside for irregularity or error, the result of the hearing was not always advantageous to the company.

Not even the zealous advocates of high percentage of return have gone so far as to contend that a fixed or certain percentage return on the entire rate base is guaranteed by the Constitution, regardless of interest rates or stock dividends prevailing. In the very able brief filed by counsel for the public utility in the $M c$ Cardle case, ${ }^{49}$ though they start off bravely by saying, "Regulation of rates should not be permitted to reduce below eight per cent. the earnings of the private capital embarked in the appellee's business," this is immediately qualified by the following:

"The national market for money, for industries and public service enterprises, has become highly competitive, and the return must be such as to enable the utilities to secure in this market the new money necessary for their business."

Counsel did go on to say "and eight per cent. has been widely recognized as the customary and required rate." Even assum-

47 Ibid. 269.

18 Supra note 3, at 296 n. 8, 43 Sup. Ct. at 549 n. 8.

49 Supra note 10. 
ing that the figure stated is correct (which on examination is not supported by the cases cited), ${ }^{50}$ nevertheless there still remains the question we raise in this article, $8 \%$ on what? $8 \%$ on capital borrowed at 5\% or received from investors on preferred and actually paying $61 / 2 \%$ ? Counsel in the $14 c$ Cardle case interpreted the rule of the Bluefield ${ }^{51}$.case to be

st. . . that the return to be allowed utility investors must be determined by the competitive conditions of the money market, so as to give them equality of treatment with investors in other undertakings of corresponding risks and uncertainties." 52

of course, but "utility investors" are not entitled, under the Fourteenth Amendment, to make 3 or 31/2\% profit on the money they borrow from other investors on the bonds of their company. They are entitled only, as the decisions hold, to a fair and reasonable return, in the light of financial conditions, on their property. And their property is the common stock. Or if it be preferred, surely they are not entitled to more than the rate they were willing to take as fixed in the contract.

The investor himself convincingly determines, by his actual investment in the utility, what is a fair return. If he buys first lien bonds at five, then he has established the fair rate of return on his money, for the company will pay him no more so long as the bonds run, or if he buys preferred at six, then six is the fair return, for the same reason. If there is to be refunding, the Commission can then determine the current rate to be paid on the new securities. But when this rate of return is established by contract between the company and the investor, why should the consumer pay more in the rates charged? This splitting up of the factual financial situation into its component parts (done every day by bànkers and investors) has not yet been done by the Supreme Court except in one case. ${ }^{63}$

Brandeis, J., said in 1922, in his opinion in the Sonthzvestern Bell Telephone Co. case:

"In speculative enterprises the capital cost of money is always high; partly because the risks involved must be covered; partly. because speculative enterprises appeal only to the relatively small number of investors who are unwilling to accept a low return on their capital. It is to the interest both of the utility and of the

50 See sugra sections a, c, e, f, and h, pp. 153, 159, 164, and 166.

51 Supra note 21.

52 Counsel in the 19rcCardle case round ap their argament for an $8 \%$ rale by saying: "It is important to leep in mind that neither the Commission, the utility, nor the Court, can control what rote of return is required to prevent starving the utility. That is dotermined by the investor, who will not put in his money where it may be discriminated against. City of Elizabeth v. Board of Pub. Utility Comm'rs of N. J., 99 N. J. Lav7 496, 123 Atl. 358 (1924)." Appelles's brief, p. 120.

63 Pacific Gas \& Electric Co. v. San Francisco, żnfra note 68. 
community that the capital be obtained at as low a cost as possible. About 75 per cent of the capital invested in utilities is represented by bonds. He who buys seeks primarily safety. If he can obtain it, he is content with a low rate of interest." oc

While all this was by way of argument against a fluctuating rate base, it nevertheless is a true statement of fact, pertinent to our present inquiry, one which, when presented at a time when the Court is concentrating its attention upon the sole question of percentage return, will be acceptable as a true statement by the entire Court.

Indeed, it is not too much to infer that Brandeis, J., foresaw the raising of such questions. For at another place in his opinion in the Southwestern Bell Telephone Co. case he points out that a plant built in times of low prices, at a cost of $\$ 1,000$,000 , with $5 \%$ thirty-year bonds to the extent of $\$ 750,000$, might later be held, under the prevailing opinion in the case, to have a reproduction cost of $\$ 1,750,000$. It would be, he said,

". . . a fantastic result to hold that a rate was confiscatory unless it yielded 8 per cent on the then reproduction cost of $\$ 1,750,000$. For that would yield an income of $\$ 140,000$, which would give the bondholders $\$ 37,500$; and to the holders of the $\$ 250,000$ stock, $\$ 102,500 . "$ s5

The majority of the Court stands by the proposition decided in the Minnesota Rate Cases:

"The making of a just return for the use of the property involves the recognition of its fair value if it be more than its cost. The property is held in private ownership, and it is that property, and not the original cost of it, of which the owner may not be deprived without due process of law."

Accepting that rule in all its strength, it still remains true that the percentage return to which the investor in common stock is entitled is not a percentage on the total base rate valuation, but such a percentage on his share of it, as, after deducting all prior obligations for fixed interest or dividends on borrowed money or capital in prior securities, will insure the owner of the common stock his fair and reasonable return. And as for. the bondholder or the preferred stockholder, they are entitled only to what by contract they were willing to accept (or what at the time of the inquiry is the current rate of return on such securities).

It may be true that the original holders of common stock of no par value in such cases as the McCardle case ${ }^{57}$ share in the

\footnotetext{
54 Supra note 3 , at 307,43 Sup. Ct. at 553.

ss Ibid. 305, 43 Sup. Ct. at 552.

36 Simpson v. Shepard, 230 U. S. 352, 454, 33 Sup. Ct. 729, 762 (1913).

st Supra note 10.
} 
increased values of the original property over the original investment, as they were shown to have done in the $11 c$ Cardle case, to the tune of stock dividends of $\$ 4,500,000$ of common, and $\$ 3,-$ 000,000 of bonds; but securities are now freely bought and sold and continuity of ownership is the exception and not the rule. There is an element of fairness in finding the value of the common today and safeguarding that property, for the owner of today's stock, like the owner of today's real estate, may be obliged to take a market value less, if it is less, and may get more, if it is greater, than the original cost.

III

Pacific Gas \& Electric Co. v. City and County of San Francisco:s

(a) The decision in the case. The Pacific case involved the constitutionality of the San Francisco 75 cent gas ordinance and deals with the period of 1913 to 1916 . The master and the court below found that the ordinance was not confiscatory. The Supreme Court reversed the court below. It rested its decision upon two grounds: first, that a rate of $7 \%$ was justified upon the record, and second, that the master had erred in failing to include in the rate base an adequate allowance for depreciation and obsolescence resulting from the introduction of patented inventions, or, in the alternative, making an allowance for the value of the invention greater than the company had paid therefor. The Court held that because the installation of the inventions necessitated new outlay of money and abandonment of property theretofore valuable, these factors must be taken into account, and, to the end that the issues might be reconsidered in view of the opinion, the decree below was reversed and the cases remitted for further disposition.

But the Court, for the purposes of its decision, was obliged to sustain the master's finding that in the instant case a 7\% return was justified. All that is said in the majority opinion on this phase of the case is the following: "We think the evidence supports the finding that a net return of 7 per centum was necessary in order to avoid confiscation." to

There is nothing in the opinion of the Supreme Court nor in the opinion of the court below to indicate how this $7 \%$ rate was arrived at, nor to indicate whether it is an over-all rate, or whether it was arrived at by a consideration of the difference between money borrowed at certain rates and money invested by stockholders on a dividend basis. How did the master arrive at this 7\%? What was the testimony upon which it was based?

ss 265 U. S. 403, 44 Sup. Ct. 537 (1924), rov'g 273 Fed. 937 (N. D. Cal. 1921).

so Ibid. 405, 44 Sup. Cr. at 537. 
Is there anything in the record to show that consideration was given to the methods by which the company secured its funds and the rates which it paid for its funds? The records in these rate cases are most voluminous, ${ }^{60}$ and not accessible to attorneys throughout the country. Examination of the record in the Pacific case, however, develops that for the first time in the history of these cases reaching the United States Supreme Court, the Court had presented to it the banker's technique for determining the rate which a public utility must pay in order to induce investors to invest in its stock. The record is so replete with valuable information and example of method that it would seem to justify comprehensive treatment here. ${ }^{61}$

(b) The technique of the proof. The controversy over the rate to be fixed was as between $8 \%$ claimed by the company and $6 \%$ claimed by the city. ${ }^{62}$ The technique of the city was found by the master to be wholly inadequate. ${ }^{63}$ Two witnesses were introduced. One had gone through the mortgage records of the city and county and gave a table of large mortgage loans, showing rates from 5 to $6 \%$. The other, an accountant, had made a study of sales prices of securities dealt in on the San Francisco Exchange, covering the period from 1907 to 1916. From this he arrived at the average net rate on bonds, $5.09 \%$ annually; municipal bonds sold by the city of San Francisco and on San Francisco Stock Exchange, 4.59\%; and stocks 5.52\%. ${ }^{\text {s4 }}$ His averages, however, were based on some stocks that sold on a yield basis as high as $14.80 \%$ and some as low as $4.58 \%$. This method was criticised by the experts for the Pacific Company, who called attention to the fact that not the sales price but the net return to the company established the cost of the money, ${ }^{03}$

${ }^{60}$ In Newton v. Consolidated Gas Co., the Supreme Court was obliged to reprimand counsel for a record of 21 volumes, consisting of 20,000 printed pages, with hundreds of exhibits. The practice of printing this entire record the court called indefensible and a practice "which we shall hereafter fecl at liberty to punish to the limit of our discretion-possibly by dismissal of the appeal." Supra note 40, at 174, 42 Sup. Ct. at 266.

61 See Mosher, Electrical Utilities: The Crisis in Public Control (1929) 24-25:

"It is almost as amateurs against professionals that the legal representrtives of the cities go forth to contend for the public's cause. Unless bolstered by special assistants whose services are expensive, to say the least, tho usual city attorneys are no match for the utility representatives. . . . As stated by Mr. Bradford: 'Most of the engineers and accountants experienced' in electric lighting, gas, water and other utilities are in the employ of private companies or expect to be so employed and for that reason they are unvilling to appear on the public's side? . . . A third discrepancy between public and private facilities in presenting cases is in the matter of funds available for the presentation of evidence. In the conduct of cases in Pennsylvania it was shown that the utilities have spent four times tho amount expended by the public agencies for the same cases."

62 Record, Pacific Gas \& Elec. Co. v. San Francisco, 1200.

63 Ibid. 1213.

64 Ibid. 797-804.

65 Ibid. 831. 
and that by bulking the stocks together and obtaining an average, stocks wholly unlike in character and representing investment hazards ranging from oil stocks to the stocks of large and well established banks of national reputation were lumped together, and that the list submitted included stocks of banks "generally classed as gilt-edged investments" and representing "assets so liquid in their nature that the prices of the stocks are governed largely by the capital, surplus and undivided profits assignable to each share." "s In addition to this testimony, counsel for the city in their brief relied on cases where rates as low as $6 \%$ and even $4 \%$ were sustained. ${ }^{67}$ Neither the master, the court below, nor the Supreme Court accepted any of these decisions as sustaining a standard rate. The technique of proof and argument adopted by the city was not successful. Compare this technique with the technique of the company.

In the first place, it called experts whom the master found to be "expert witnesses of the highest qualifications." One was Vice-President and one of the managers of the Wells Fargo Nevada National Bank, which the master described as "one of our largest institutions." The other had carried "the tremendous responsibility ... of obtaining the vast sums of money that the growth of the Pacific Gas \& Electric Company has required." And the third was a man of wide experience in the field of investment securities. With the aid of these experts, the Pacific Company ${ }^{\circ}$ covered the following ground:

(a) the financial history of the company;

(b) the rates it was obliged to pay in order to secure capital;

(c) the special circumstances connected with raising money in San Francisco;

(d) the general financial market situation at the time the ordinance was brought under review, i.e., 1914 to 1916;

(e) an opinion as to the over-all rate necessary in order to insure the company's ability to raise additional capital.

The finding of the master of $7 \%$ is an over-all rate, and in arriving at his result he adopted the technique of the banking experts offered by the company. Lipman, one of the three experts, testified

“... that any time and place there are a variety of rates current for loans and investments; that these rates vary materially, the difference being fundamentally due to differences in

G6 Ibid. 836.

67 Counsel cited Lincoln Gas Co. v. Lincoln, supra noto 35, for an established rate of 6\%; Cedar Rapids Gas Co. v. Cedar Rapids, supra note 23, for 6\%; Willcox v. Consolidated Gas Co., supra note 25, for 6\%; Knoxville v. Knoxville Water Co., supra note 39, for 4 \%o; Denver v. Denver Union Water Co., 246 U. S. 178, 38 Sup. Ct. 278 (1918) ( $4.28 \%$ held insdequate). 
risks; risks of loss, risks of delay, risks of uncertainty, and risks of inconvertibility." 88

He furthermore testified with reference to the general financial conditions in San Francisco:

"During the panic of 1893 and that of 1907 and also after war broke out in Europe in 1914, there was a condition of severe stringency affecting interest rates in all classes. . . . State and other gilt edge bonds, now $3.8 \%$ to say $41 / 2 \%$, were difficult of sale at $5 \%$ or even $6 \%$ and upwards. Loans on mortgages were practically unobtainable at any rate and fresh capital for new enterprises was absolutely unobtainable."

The influence of these conditions lasted much longer, "being a considerable factor in the investment situation for a protracted period." The high level was maintained from about 1905 to 1914. "Since the war began business conditions have been so upset that it is quite impossible to distinguish between what is normal and what is exceptional." He referred further to the effect of the San Francisco conflagration, in consequence of which:

"From 1907 to 1914, capital for permanent investment had frequently been so scarce in New York and in the other Eastern markets, that our California corporations have had to bid very high rates to obtain supplies for use here, instances being known where the cost was upwards of $10 \%$." 69

Hockenbeamer, another of the experts, listed at length the reasons why there was difficulty in marketing the Pacific Company's securities..$^{70}$ First he brought out that California is an earthquake country and that utility properties therefore are liable at any time to suffer extensive damage. He also pointed out that local taxes were exceedingly high in San Francisco, that there were severe inheritance taxes, and, moreover, that the stockholders were liable to assessment. ${ }^{11}$ He gave the financial history of the company, from which it appeared that in 1907 the company realized $\$ 7,523,100$ in cash for $\$ 8,359,000$ of stock.

\footnotetext{
68 Record 686.

68 Ibid. 688.

70 Ibid. 746.

71 Ibid. 737-739. In 1907 the entire issue of twenty million dollars of the company's common stock reverted to its treasury through purchase by the company at public sale, following the failure of the owners to pay an assessment of ten dollars per share, preferred stockholders at the same time paying an assessment of one million dollars on their stock. In consequence, it was pointed out that the common stockholders tale "the major risks of the enterprise by guaranteeing both the bonds and preferred stock unless, in the event of financial difficulties, they accept the alternative of losing their entire investment."
} 
The same year it issued $\$ 3,883,000$ of stock as a bonus at the rate of $100 \%$ of stock to $100 \%$ of bonds carrying $6 \%$. In 1908 and 1909, in order to sell 5\% bonds, it issued a $100 \%$ stoclr bonus aggregating $\$ 1,063,900$, and in 1910 and 1912 it sold for $\$ 2,015$,000 in cash $\$ 3,500,000$ of its common stock. He attached a table to his testimony which showed that the average cost of the company's money for the years 1912 to 1916 inclusive was on its 5\% thirty-year bonds 6.20 , on its first preferred $6 \%$ cumulative stock 7.40, and on its one year gold notes, $19136 \%$ and $19145 \%, 9.30$.

Lipman testified that a public utility corporation which had already established its business could not obtain additional capital on the basis of a return of less than $7 \%$, unless it had already accumulated a substantial surplus "and unless its earnings are substantially in excess of the amount required for the payment of interest and dividends upon its outstanding securities." 72 Weeks, another expert, who was associated with one of the large investment banking concerns in the country, dealing both in New York and San Francisco, testified:

"Logic and experience alike indicate conclusively that the rate of return which a utility must earn on the total investment in its property, in order to be able to raise the capital necessary to its operation, must be in excess of the rate on which it can borrow a portion, say $60 \%$ or $75 \%$ of the capital required against a fixed obligation on the part of the owners or stockholders to pay interest on the sum so borrowed and to repay the principal thereof at a definite time, and against the security of a mortgage covering the property of the corporation." 73

These quotations indicate clearly that the 7\% rate fixed by the master and confirmed by the United States Supreme Court was an over-all rate, but in arriving at this figure the Court took account of the rate at which the company could borrow on its bonds and the rate at which it could raise money on its assessable stock."

72 Ibid. 707.

73 Ibid. 710. Cf. also ibid. 709:

"Experience in the financing of public utility and other similar properties has shown that the most practical and most economical method of obtaining the necessary capital has been through borroving a conservative proportion ranging from $50 \%$ to $85 \%$, but ordinarily not more than $75 \%$, of capital requirements by the sale of mortgage bonds, the balance of the money required for the construction or acquisition of physical property, worling capital, and the developing of the business, being obtained by the sale of stock. In some cases all of the stock sold is in the form of common stock; in other cases, a portion of the stock is preferred, frequently difierent classes, such as 'First Preferred', 'Second Preferred', etc., being authorized and Eold."

Is Nowhere have we found a better statement of the fundamental difierences between the fixed obligation to pay and the stock investment, especially where the stock is subject to assessment as in California, than in the following testimony: 
Hockenbeamer presented an example for raising money in such a public utility as was then under consideration, based on raising $60 \%$ in bonds, $20 \%$ in preferred stock and $20 \%$ in common..$^{75}$ To obtain $\$ 100$ :

$\$ 60$ bond money at $6.20 \%$ requires

$\$ 20$ preferred stock money at $7.40 \%$ requires

$\$ 3.72$

1.48

$\$ 20$ common stock money at $8 \%$ requires

1.60

6.80

Assuming a margin of safety of 2.25 for common stock, the total requirement would be $9.05 \%$.

The master adopted this example, saying:

"Mr. Hockenbeamer . . . has done a service in making explicit and obvious the fact that rates of cost of money such as those quoted above are contingent on the existence, not only of a margin or surplus of capital behind the money loaned or invested, but of a margin of earnings above the amount necessary for interest and dividends." 70

"Mr. Hockenbeamer also believes that if the company could earn 8 per cent dividends on its common stock and a margin or surplus equal to those dividends, it could sell its common stock at par and obtain its bond money on a 6 per cent basis and its preferred stock money on a 7 per cent basis. On this theory he makes an alternative computation, thus:

$\$ 60$ bond money @6 per cent ............ \$3.60

$\$ 20$ preferred stock money @7 per cent... 1.40

$\$ 20$ common stock money @8 per cent.... 1.60

Margin of safety for common stock........ 1.60

Total $\ldots \ldots \ldots \ldots \ldots \ldots \ldots \ldots \ldots \ldots \ldots \ldots$ 8.20"

\footnotetext{
"There is a fundamental difference between the loan of money against an obligation to repay it in full secured by collateral, which obligation is held by a bondholder or a noteholder, and the position of a stoclcholder, the owner of a property, charged with all the duties and obligations involved in ownership, including the control and management of the proporty, the return to bondholders or noteholders of money borrowed from them, with interest thereon, and the performance of all the other obligations of an owner." Ibid. 712 .

75 Ibid. $783-784$.

76 Ibid. 1208. Cf. also:

"We must disabuse our minds at the outset of the notion that the face rate on government or other bonds, on preferred stocks or on secured notes has any but a remote bearing on the subject. We must also bear in mind the greater risks of any business enterprise; the fact that the cost of money embodied in the sale of securities is greater than the faco rato paid the investor by the amount of discount and other expense incident to marketing the securities, and paying trustees, coupon-paying banks and others during their life; and, finally, that the securing of money at a given cost, if favorable, implies a margin of earnings above that cost. Tho reasonable rate is sometimes defined as that rate of earning which will attract necessary capital to the enterprise; sometimes as that which is customarily earned in business of equivalent risk. I emphasize the point that it is a rate to be earned, not necessarily one to be paid by the utility." Ibid. 1207.

ir Ibid. 1209.
} 
Here we have complete and perfect proof that if we pay $6 \%$ on $60 \%$ of the money required as first lien bond money and $7 \%$ per annum on $20 \%$ of the total required in preferred stock, the company does not need an over-all rate of more than $8.20 \%$ in order to sell its common on a basis of $8 \%$ per annum, allowing a margin of safety per annum of $1.60 \%$. But suppose it should appear that not $60 \%$ but $75 \%$ is obtainable and that it is obtainable at $51 / 2 \%$, that $20 \%$ additional is obtainable at not more than $61 / 2 \%$ and that but $5 \%$ of the total capital required . is obliged to pay the $8 \%$ rate, the figures would then be:

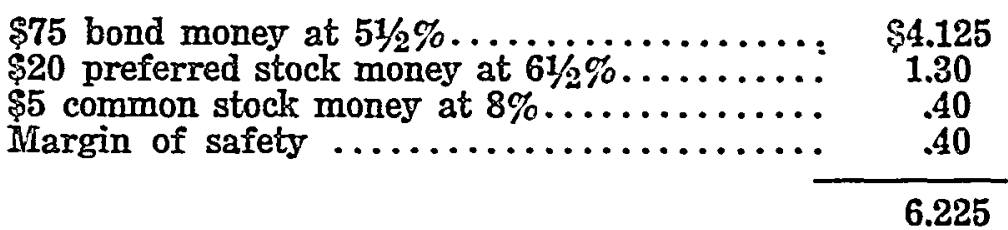

It seems clear that to determine the fair rate the court must consider:

(a) the company's borrowing capacity;

(b) the rate of interest it must pay on its bonds;

(c) the amount it can raise on bonds;

(d) the preferred stock; what dividend rate?

(e) the security of the company behind the dividends in way of surplus, other earnings, etc.

It follows that the trier of the facts must analyze the company's financial set-up, its actual experience in raising money, and the actual returns to investors required to get new capital.

It must be recalled that the Pacific company did not confine its operations to San Francisco, nor to manufacturing and purveying gas, though it was the only purveyor of gas in San Francisco. A large part of its business lay elsewhere, through some thirty different counties in California. It owned gas works in a number of cities and great hydro-electric and steam plants, generating electricity for light and power, serving many towns and rural communities. It owned a street railway in Sacramento and a water system in the foothills of the Sierras. The Pacific company, therefore, in its relationships to the business of gas purveying in San Francisco, was a holding company. There appeared to be no other way by which the master could be furnished with evidence from which he could find the overall rate required by the company to induce capital to invest in the enterprise than by considering the whole of its financing. The logic of the situation would seem to require that the same technique be applied when the trier of the facts is to fix a rate of return which shall not be confiscatory, where the property in use is part and parcel of a holding company system. 
It will be observed that the master did not allow $9.05 \%$ or $8.20 \%$; he allowed only $7 \%$, and he was sustained by the Supreme Court. He eliminated the margin urged by the company's experts, computing the cost of money at $6.60 \%$ or $6.80 \%$ and thus allowed a margin of $.20 \%$ or $.40 \%$ as the case may be. $\mathrm{He}$ based this primarily upon the fact that $7 \%$ was testified to by two of the banking expert witnesses as a minimum fair rate of earning and that the higher cost to the company of its money during the years 1913 to 1916 was not a necessary criterion.

(c) Applying the technique of proof to the new financial situation. The portrait of the investor of 1914-16 in San Francisco public utilities as painted by the financial experts in the Pacific case bears as little resemblance to the general investor of 1929 as Holbein's drawing of Henry VIII bears to our own portrait of Henry Ford..$^{78}$ The modern investor to whom appenl is made is the common "man in the street." Knowledge of securities, the earning power of utilities as compared with industrials, the difference in yield. on gilt-edged bonds, as compared with dividends on common or preferred, is broad and general. The growing withdrawal of savings banks deposits shows the trend of the day. Investment houses have by a long series of intelligent education created this general market for securities. They have used and are still using the radio. They distribute carefully prepared pamphlets as well as analytical studies of earnings, present and prospective. Books on profits in long holdings of bank and insurance stocks are written. We are a nation of investors today, common stock owners as well as bondholders. There is competition for our dollar. ${ }^{70}$

A reputable daily can report that municipal bond houses expect to attract long range investors toward municipal bonds by analyses showing that common stocks normally considered "safe and suitable investments for surplus funds are yielding less in dividends than the highest grade bonds." so On July 19, 1929, Atchison, Topeka \& Santa Fe common, paying 10\% per annum, sold for 257 7/8. Canadian Pacific paying 10\% sold for 245 . (Its high in 1929 was $2657 / 8$ ) New York Central, paying 8\%, sold for 240. Investors buying bank and insurance stocks for long time investment buy not on the basis of the annual yield, which sometimes is as low as $3 \%$, but buy in expectation of later distribution of increased surplus in stock subscription rights,

\footnotetext{
${ }^{78}$ See HaCketT, Henry The Eighth (1928) 417, 429-30.

${ }^{70}$ The debacle in the stock market since this article was written does not change these conclusions. "Odd-lot" buyers rushed to the market for "bargain counter" investments, and got them.

${ }^{80} \mathrm{New}$ York Herald Tribune, July 15, 1929, at 1.
} 
split-up of stock, stock dividends, etc. The average yield of industrial shares around July 1, 1929, was 4.9\%.81

The Court must take notice of the fact that probably for the first time in the history of this country there is a videspread investment movement in the direction of long term investments in stock wherein the investor looks forward to capital increment rather than to annual dividend return.

As this section of the article is being written there comes striking confirmation of the need for a complete recasting of the financial picture which the United States Supreme Court has ${ }^{\circ}$ had presented to it in rate cases during the last decade. The Middle West Utilities Company announces a complete reorganization of its financial structure, involving the complete retirement of its $8 \%$ prior lien and its $8 \%$ preferred stocks, in lieu of which it proposes to issue common stock rights to all classes of stockholders. The new preferred which it will issue will carry a $6 \%$ dividend, payable in cash or in common stock, at the option of the holder. The common stock will pay dividends not in cash but in the form of common stock, at the annual rate of $8 \%$ of the number of shares held. For example, the holder of 100 shares of common will receive as dividend thereon two shares quarterly, or eight shares annually. ${ }^{82}$ The president of the company announces that the plan is backed by

“. . . the striking economic growth throughout the entire territories served by the Middle West Utilities system, which places upon the company the responsibility of continuously increasing the facilities for service. To do this it is necessary to have a financial structure capable, under present-day investment conditions, of maintaining a continuous flow of invested capital."

By one stroke the company will cut out the $8 \%$, annual payments required on its prior lien and $8 \%$ preferred stocks, which

81 Ibid. July 14, 1929, at Section XIII. It was 4.7\% the first of the year, according to a compilation by the Standard Statistics Company, of New York, it appearing that dividend rates had increased at a relatively faster nace than stock prices. The table showed that the highest gield was 7.3\% (cotton goods) while the lowest was 1.7\% (aircraft).

See also chart shoping "The Long Term Trend of Security Yields" (Nev York Herald Tribune, July 28, 1929, Section XIII) published by the Standard Statistics Company, showing that $\mathbf{5 0}$ industrials have steadily gone down to a yield of between 3 and $4 \%$, but 33 industrial common stocls have steadily gone down from a peak in 1917 of between 8 and $9 \%$ and a peals in $1920-21$ of $8 \%$ to very close to $4 \%$ at the end of 1928, and that 20 high grade preferred stocks have gradually gone down to a yield of $535 \%$.

82 To bring this about, the company will offer to its present stocltholders common stock rights on the basis of one nev share at \$200 for each four shares of all classes now held. At this rate, as the stock is now selling around 355 , on a.10 for 1 basis, it is estimated that nearly 67 million dollars in rights to stockholders is thus being distributed. New Yorls Herald Tribune, Aug. 4, 1929, Section XIII, at 1 . 
are to be called for redemption. As this is a holding company, it is quite obvious that the first lien securities on the utility companies which the holding company controls will not even have to pay $6 \%$ per annum. In the light of this new development, this modern type of finance, resulting from a new attitude of mind on the part of the common stock investor who looks now to the future by way of securing new shares in capital ownership, rather than to the immediate present by way of annual yields, must there not be a complete revision of such percentage figures as the Supreme Court has had before it in determining the over-all rate?

Investors now understand that earnings of public utility companies are not confined to the utility properties used in the public service. A recent article points out that "other income" in the case of five railroads was equivalent to nearly $50 \%$ of the net earnings from railway operations and that one railroad alone in a short time will be taking in enough interest and dividends from its investment securities to cover fully the current $\$ 10$ dividend on its common stock. ${ }^{83}$ Publication of American Telephone \& Telegraph Co. earnings for the first half year of 1929 showed operating revenues of $\$ 48,495,536$, and "Dividends and Interest" aggregating $\$ 63,983,615$. When this appeared, it quickly reflected itself in a rise of the market of the common stock. The oil properties of Atchison and the nickel mines of Canadian Pacific contribute alike to the common stockholder's confidence in his investment. He expects some time to realize on the capital assets.

The special master in the Pacific case said, "It may be true now that electricity has a surer market and a more certain basis of production than gas." ${ }^{84}$ He was prophetic. The Pacific Company would hardly recognize herself today in her portraits of fifteen years ago. Her net income has doubled in the last seven years. The reductions in electric rates alone have aggregated an amount equivalent to twice the annual dividend requirements on the outstanding common stock. The company has now (as contrasted with 1918) total reserves of around $\$ 26,000,000$ and a profit and loss surplus of fifteen and a half millions. Its capital is now over $\$ 207,000,000$. Early last year it sold an issue of $\$ 20,000,000$ first and refunding mortgage $41 / 2 \%$ series $E$ bonds on a basis costing the company "but $48 / 4$ per cent, the lowest in its history." These bonds are followed by two issues of preferred stock, about $\$ 79,000,000$ in first preferred, carrying cumulative dividends at the rate of $6 \%$, and about $\$ 4,100,000$, also first preferred, with cumulative dividends at the rate of $5 \frac{1}{2} \%$. "The present rate of $\$ 2$ a share annually"

83 Standard Statistics, July 5, 1929.

84 Record, supra note 62, at 1210. 
on its common stock "is equivalent to $\$ 8$ a share on the old stock, which was receiving payments on that basis prior to its exchange for the shares now outstanding." Here is a picture so different from the one presented in the case which went to the Supreme Court that it is not conceivable that on such a record a $7 \%$ over-all rate could be sustained.

The Court has but recently admonished the bar in the Sinclair ${ }^{85}$ case that, in reading its opinions, "Always the language used in an opinion must be read in the light of the issues presented." New factors of immense financial importance, not yet presented to the Court, will call for new applications of its principles.

Yet the exceptionally competent financial experts in the Pacific case gave us, as we have seen, a reasonable technique of proof by which to determine what constitutes a "fair and reasonable return" on "business dedicated to a public service." While the Court may take judicial notice of changed economic conditions generally (as it has done on other occasions), ${ }^{80}$ evidence should now be presented bearing upon such important factors as the market conditions of the time and the cost of money to the utility, etc. Even to establish an over-all rate of $7 \%$, it was necessary in the Pacific case to show a set of circumstances indicating great local difficulties in financing, as well as general war-time and after war-time conditions, earthquake hazard, assessment liability on the common, etc.,一all intended to establish an over-all rate of but $7 \%$.

Let us, then, by way of example, apply the technique of the Pacific case, changing only the facts to reflect more accurately present day finance. To raise $\$ 100$, it will cost per annum, we will say,

$\$ 75$ 1st lien bonds at $51 / 2 \% \ldots \ldots \ldots \ldots \ldots \ldots . \quad \$ 4.125$

$\$ 10$ preferred at $6 \% \ldots \ldots \ldots \ldots \ldots \ldots \ldots$

$\$ 15$ common split up by means of the holding company device into:

$\$ 101$ 1st debentures at $6 \%$............... $\quad .60$

$\$ 21 / 2$ 1st preferred at $7 \% \ldots \ldots \ldots \ldots \ldots \ldots \ldots \ldots \ldots . .175$

$\$ 21 / 2$ common at $8 \% \ldots \ldots \ldots \ldots \ldots \ldots \ldots \ldots \ldots . .20$

$\$ 5.70$

If we double the return on the common, as Pacific's expert did, we add $\$ .20$, making $\$ 5.90$, or less than $6 \%$ over-all rate on the whole. Now, if, instead of a $6 \%$ over-all rate, the utility is allowed $8 \%$, it will receive on the whole amount of $\$ 100, \$ 8.00$.

85 See Sinclair v. United States, 279 U. S. 749, 767, 49 Sup. Ct. 471,477 (1929).

${ }^{86}$ Cf. Willcox v. Consolidated Gas Co., supma note 25, with Nerton v. Consolidated Gas Co., supra note $\mathbf{1 0}$. 
It will pay out to all except the common stockholders of the holding company $\$ 5.50$, leaving $\$ 2.50$ to pay on a $\$ 2.50$ investment, or $100 \%$ per annum to common stockholders on their investment. 87

To enable the rate-regulatory body to determine what "should be adequate, under efficient and economical management, to maintain and support its credit and enable it to raise money necessary for the proper discharge of its public duties," 80 the company's financial structure must be examined. In the very nature of the case it would seem that there must be considered not only its financial history, its stability and earning power, surpluses and reserves, but also the rate at which it has borrowed money, the amount it can raise on its bonds, on its preferred stock, and on its common stock, and the general practice at the time the rate is fixed for raising such funds. Moreover, there must be regard for two other factors: first, the ratio of the amount which it can pay at low interest rates on borrowings as compared with the dividends it must offer investors in its common stock; and finally, the' amount over and above such a reasonable dividend rate as will insure safety to bondholders and a reasonable assurance to preferred and common stockholders that their dividends will be paid. The new technique will require the fact-finding body to go through the processes which investment bankers go through in determining marketability of securities. Hence the financial set-up of the company, the relationship of its earnings to other assets, its common stock value as represented by a holding company split-up-all must be analyzed and considered.

If this be done, it would seem then that the large returns to a comparatively small group of controlling stockholders in holding companies must come down. It is inconceivable that, when it is properly before it, the Supreme Court will not apply to the new factual situation its own past rulings, $i$. e., the distinction between ordinary business and industries "affected with a public

87 That these figures are not exaggerations but are in line with actusl conditions is shown by news from the Chicago Stock Exchange (coming, as it happens, as this part of this article is being written: New York Times, July 20, 1929), from which it appears that from June 30 to July 19, 1920, the common stock of one utility holding company rose from 15 to 94 , an appreciation of $\$ 79$ a share, or a total of $\$ 63,000,000$; but it is stated that those who own the common did still better and their profit is estimated to be at around 94 millions. This result had been achieved on a marketing of debentures and prior preferred, the debentures carrying but $5 \%$, but accompanied with an option to buy 50 shares of common with each $\$ 1000$ bond at $\$ 15$ per share. The preferred rate is not given but it was accompanied with a right to subscribe for five shares of common at $\$ 15$ for each share of preferred.

88 Bluefield case, supra note 21 , at 692,43 Sup. Ct. at 679. 
interest," as well as its rules for determining rates properly chargeable to consumers. In the recent Dayton-Goose Creeli case it said concerning the right of stockholders in a business dedicated to a public service:

"By investment in a business dedicated to the public service the owner must recognize that, as compared with investment in private business, he can not expect either high or speculative dividends, but that his obligation limits him to only fair or reasonable profit." ${ }^{80}$

It will not deter the enterprising pioneer by depriving him of the large returns in increased stock dividends (as it did not in the $A I c$ Cardle case) but on the other hand it will not, it would seem, continue to guarantee to the stockholder of a holding company a rate of return which, on analysis, is shown to net him, after the enterprise is on its feet, $100 \%$ or more per annum. Whether the over-all rate in any given case shall be $6 \%, 7 \%, 8 \%$ or more will depend upon the financial conditions prevailing at the time of the inquiry. But we are reminded again that even upon such a record as was presented in the Pacific case, concededly one indicating bad marketing conditions for the company's bonds, its preferred and its common stock, the utility's effort to secure an $8 \%$ over-all rate failed and the master's finding of $7 \%$ was sustained.

It will be no answer to say that because rate-regulating bodies have no jurisdiction over holding companies they are not concerned with the stock or debentures of such companies. In determining values for the rate base, the court may consider, but is not bound by, the amount of the company's outstanding stocks and bonds. But this relates to only one phase of the inquiry, namely, the determination of the value of the property "used or to be used in the service devoted to the public," while, on the other hand, "whether a rate yields such a return as not to be confiscatory depends upon circumstances, locality, and risk." ${ }^{20}$ Hence, in order to determine the credit borrowing capacity of the utility, the regulating body (or the court on review) must inquire into all the details of the financial structure of the company. For the same reasons, whether it can regulate holding companies or not, it must examine the reality of the situation.91 It cannot be fooled by stopping the door of inquiry at the rate of dividend paid on the common stock, which

\footnotetext{
${ }^{89}$ Dayton-Goose Greek R. R. v. United States, 263 U. S. 456, 481, 44 Sup. Ct. 169, 173 (1924).

${ }^{80}$ See the Bluefield case, supra note 21 , at 693,43 Sup. Ct. at 679.

91 The Supreme Court has not looked with favor upon devices designed to aid a corporation by reducing its net earnings so as to establish a rate as confiscatory. See Chicago \& G. T. R. Co. v. Wellman, 143 U. S. 339, 345, 12 Sup. Ct. 400,402 (1892).
} 
in turn is held by a holding company. Since it is not the dividend which is paid, but the rate of dividend necessary to enable the utility to get the money that is to be determined by the factfinding body, it must inquire into the complete factual situation.

Nor will the courts be dissuaded from this task by the fears prevailing in 1916-17 and the years immediately following. Speculative returns may still be justified in new pioneering enterprises. But it cannot be argued that highly speculative profits are now needed for our seasoned public utilities such as power and light. The reasoning which kept the Pacific Company down to a 7\% over-all rate should keep the over-all rate down in enterprises still better situated.

Neither will the Supreme Court be dissuaded by fear of the effect on general economic and social conditions of lower rates. Too much is available in the way of material already published by governmental agencies indicating the fact that low utility rates, especially of light and power, mean improved industrial and social conditions. The clamor is for "cheap power" to compete with other markets. This demand will increase when the competition of foreign industries with cheap governmentally developed power will force itself upon our attention.92

Mr. Justice Peckham said in Wilcox v. Consolidated Gas Co.:

"The elevated railroads in New York when first built charged 10 cents for each passenger, but when the rate was reduced to 5 cents it is common knowledge that their receipts were not cut in two but that from increased patronage the earnings increased from year to year, and soon surpassed the highest sum ever received upon the 10 -cent rate." ${ }^{93}$

It was this reasoning which led him also to say :

"And again, increased consumption at the lower rate might result in increased earnings, as the cost of furnishing the gas would not increase in proportion to the increased amount of gas furnished." ${ }^{9}$

The newly elected president of the National Electric Light Association, Matthew S. Sloan, says (1929) that it is

"... more than a coincidence that in every case I know of a reduction in domestic electric rates has been followed by increased use of service. There may be instances where this was not true, but they have not come to my attention. It was true in Brooklyn under conditions which covered a series of reductions over a period of several years. It has been true in up-state New York, in New England, in the Middle West, and on the

92 Consider also such projects as governmentally developed hydroelectric power at Boulder Dam, Muscle Shoals, and on the St. Lawrence River.

${ }^{93}$ Supra note 25, at 51, 29 Sup. Ct. at 199.

94 Ibid. 
Pacific Coast. These companies which show the highest annual domestic sales also show the lowest rates. We have, therefore, in the experience of our industry, what may be accepted as a guiding principle in stimulation of sales of service for domestic use. The way to increase such sales is to wisely and properly lower the domestic rates." 05

It was Mr. Ford who blazed the way for the newer economic policy of widening the field of consumers by selling at a low margin of profit. So we have seen, leaders in the public utility field are now advocating strongly the reduction of rates to widen the use of electricity, gas, telephone, etc. It thus appears that lower rates may indeed result in larger earnings for the stockholders.

- (d) New capital increment through valuation of patents. One other point comes within the scope of this article, interreated with our consideration of the Pacific case. It will be re:alled that the master fixed, as the value of the patents, the sum if $\$ 46,066.68$ and said he took this figure because it was the best igure offered to him in the way of proof. It was the sum api earing upon the books of the company as paid to the inventor zor the patents. Regarding the plant thus replaced, the master • : ssumed that this had already been covered by write-ofis for depreciation. It was the duty of a prudent company, he said, to set up annual reserves for such obsolescences. This Spartan viewpoint the majority of the Supreme Court refused to accept. It said that one of two things should have been done. Either the master should have made an adequate allowance for part of a plant rendered obsolete by the introduction of the patents, or he should have ascertained the value of the patent and trented it as one of the capital assets forming part of the rate base. The Pacific Company's experts urged that the value of this patent was $\$ 4,203,300$, or a little less than one hundred times what the company had paid for it. They arrived at this valuation, as appears from the record, by a process such as is used in patent litigation, by capitalizing the earning value of the patent over the life of the patent. If a patent will earn, say, a thousand dollars a year, these experts argue it is worth that sum which will produce a thousand dollars a year for the legal or estimated life of the patent. Now the Supreme Court did not say this method must be followed. But as we have seen, it could not reverse the court below, as the minority pointed out, unless it believed the real value of the patents to be a very substantial sum, more than enough to wipe out the margin of safety etill left in the figures of earnings on a 7\% basis. ${ }^{\circ 0}$ The Court

os New York Evening Post, July 29, 1929.

${ }_{96}$ The master found, and the court below adopted, as the reasonable value 
gave no clue as to what method it believed should be followed in estimating the value of the patents, but sooner or later it wiil be obliged to pass upon this question. Then it will have to meet this query: Since the earning value of an untested patent or one tested for but a brief period is a mere prophecy by experts, are consumers of a public utility to guarantee the fulfillment of the experts' prophecies? In short, if the experts say the patents are worth a capital sum which will produce annually the amount which, in their opinion, they say it will en:n, is the rate base to include this item and thus put upon the consumers the burden of paying an amount which is necessary to insure to the utility the fulfillment of the experts' prophecy? How much of the Pacific Company's enhanced success in the investment world was due to the Court's decision on this point of patent values, we are, of course, unable to say, but nothing could be more certain to add to the readiness with which investors will absorb utility common stocks or utility holding com. panies' common, on the basis of prospective additional increases in capital, than the assurance that every new savings device introduced will be certain of realizing the prophecies of the experts in the way of increased profits. It would seem, therefore, if we are to recognize the rule that stockholders who have engaged in a public service are limited to a fair or reasonable profit, that the rates necessary to secure new capital must be reduced. In other words, it can hardly be expected that the Supreme Court will sustain a method of rate making by which common stockholders secure both capital gains and the high annual rate returns. Such a method savors too much of stuffing the goose

of the properties used and useful and reasonably necessary to the manufacture and distribution of gas in the area under consideration for tho year 1913 to 1914 , including working capital, the sum of $\$ 13,976,435$. Taking $7 \%$, or $\$ 978,350.45$, as a reasonable return on the capital investment made a total of $\$ 3,384,129.56$. The total revenue at the ordinance rate was $\$ 3,405,532.51$, or $\$ 21,402.95$ in excess of the $7 \%$ return on the capital investment.

Taking the $7 \%$ figure on $\$ 4,203,200$, if $7 \%$ is the rate allowed, the company would be required to earn $\$ 294,231$, which would not be covered by the figures referred to. The minority, Brandeis and Holmes, JJ., were of opinion that the question was not one of continuing importance to the parties, since its correctness depended upon the state of the particular record and that any defect in the record could be avoided in proceedings concerning the rates for any year after June 30, 1916. "Only a largo undorvaluation would affect the result, as the master and the court found that during the year 1914-1915 the prescribed rate would yield $\$ 89,446$ in excess of a $7 \%$ return on the rate base, and for 1915-1916, an excess of $\$ 171,464 . "$ (See footnotes 6 and 7, 265 U. S. 403, 421, 44 Sup. Ct. 537, 543.) But it is apparent from a reading of the majority opinion that the Court was quite ready to believe that "a large undervaluation" did affect the result, and based upon this belief it held the ordinance unconstitutional and remitted the cases for further disposition. 
with a continuous filling of golden eggs to make sure of the continued production of golden eggs.

We can do no better in closing this article than to turn to the guiding principle laid down by Harlan, J., in the Covington Tumpike case as far back as 1896:

"It cannot be said that a corporation operating a public highway [utility] is entitled, as of right, and without reference to the interest of the public, to realize a given per cent upon its capital stock. When the question arises whether the legislature has exceeded its constitutional power in prescribing rates to be charged by a corporation controlling a public highway, stockholders are not the only persons whose rights or interests are to be considered. The rights of the public are not to be ignored. ... In short, each case must depend upon its special facts; and when a court, without assuming itself to prescribe rates, is required to determine whether the rates prescribed by the legislature for a corporation controlling a public highway [utility] are, as an entirety, so unjust as to destroy the value of its property for all the purposes for which it was acquired, its duty is to take into consideration the interests both of the public and of the owner of the property, together with all other circumstances that are fairly to be considered in determining whether the legislature has, under the guise of regulating rates, exceeded its constitutional authority, and practically deprived the owner of property without due process of law. What those other circumstances may be, it is not necessary now to decide. That can be best done after the parties have made their proofs." or

97 Covington \& L. Tumpike Rd. Co. v. Szndford, 164 U. S. 578, 596, 597, 17 Sup. Ct. 198, 205 (1896). 


\section{APPENDIX}

Besides the Supreme Court cases discussed in this article a number of other cases have been cited for an "8\% customary and required rate," notably by eminent counsel in the McCardle case. We subjoin an analysis of these cases, showing that none of them sustains any such rate, but the utterances of the courts are, as usual, to be read in the light of the facts presented. Not one of them considers the rate as an "over-all" rate as was done in the Pacific case, supra.

Pioneer Telephone \& Telegraph Co. v. Westenhaver, 29 Okla. 429, 118 Pac. 354 (1911). The full extent of this case is disclosed in the syllabus prepared by the court itself:

"Rates charged by a telephone company for services of a telephone exchange that yields only sufficient revenue to pay operating expenses and fixed charges, including a reasonable amount for depreciation, and a return of approximately $5.5 \%$ per annum (less than the legal rate of interest) on the value of the properties used in rendering the service, held not excessive, oppressive, or unreasonable to the public."

The figures in the case are very simple. Net earnings for 1908, after deducting all expenditures, were $\$ 6,151.84$, which made but $5.5 \%$ on the sum of $\$ 113,596.42$ which the court found to be the present value of the plant. In this case the court was influenced by the fact that $6 \%$ was the legal rate of interest. There was no consideration of the financial set-up of the company and no separate consideration of the varying rates to be paid for bond money or preferred or common stock.

McAlester Gas \& Coke Co. v. Corporation Comm., 102 Okla. 118, 227 Pac. 83 (1924). The entire case dealt with the application of rules for determining the rate base. The rate of return was not discussed. The court said, in passing:

"The testimony in this cause, as produced by the appellants upon the questions of depreciation and amortization, authorizes an allowance of $17 \%$ upon the net value for these purposes, also $8 \%$ on such valuation for return to the owners. There was no testimony to the contrary." Ibid. 123, 227 Pac. at 87.

Alton Water Co. v. Illinois Commerce Comm., 279 Fed. 869 (S. D. Ill. 1922). Examination of the case discloses that the rates proposed would yield only from one-half of $1 \%$ to $11 \% 2 \%$ on the present value of the utility's property. It was held that this was confiscatory. The court said:

"It has been held that no rate of return can be deemed reasonable which is not high enough to attract capital to the form of investment involved in utility properties, such as complainant's. A return of 8 per cent upon the fair value has been held to be reasonable." Ibid. 873 .

But, as we have shown, $6 \%$ has also been held to be reasonable, and so has $4 \%$.

Indiana Bell Telephone Co. v. Public Service Comm., 300 Fed. 190 (D. Ind. 1924). Here the court gave the rule clearly:

"Leaving out of consideration the question of what may be in any given case a fair return for the user to pay for a service, the fair return, generally speaking, is such an amount as would at the time of the inquiry induce the investment of money in such a utility. Money will not be invested in utilities unless the probable return will be at least equal to the return on 
securities of like kind and character; otherwise many communities rould be left without necessary utilities until they could be established under public ownership. One method of arriving at these conditions that pould induce investment in public utilities is by testimony showing the rate that securities of like lind and character command in the marlet." Ibid. 201 .

The figures in the case showed, from the comparative statements made by the court, that a $6 \%$ return would require $\$ 2,039,653.36$ annually, while net earnings on the basis of the Commission's order frould produce but $\$ 1,607,-$ 162.07. The Commission's order was found to be not sustainable, even on a $6 \%$ rate, after the court had made its modifications in the rate base.

Michigan Public Utilities Comm v. Michigan State Telephone Co., 228 Mich. 658, 200 N. W. 749 (1924). There wos no consideration given to the rate of return, because, as appears from the opinion, the complaint of the rate of return fixed by the Commission at 7\% "is not pressed and will ba passed."

In Consolidated Gas Co. v. Prendergast, 6 F. (2d) 243 (S. D. N. Y. 1925), a detailed table showing comparison of returns for 1922, 1923 and 1924 indicated what would be required on either a $6 \%, 7 \%$ or $8 \%$ return, computed on. either investment cost figares, reproduction or so-called present cost values, from which figures the special master concluded:

"From the preceding figures it will be seen that in neither jear and under neither the past nor present prices would the company have earned a return of even as much as 6 per cent. on its investment or reproduction cost or present value." Ibid. 273.

The figures showed a reproduction cost for 1922 of $\$ 159,710,750.73$. A $6 \%$ return would be $\$ 9,582,645.04$. The actual return in 1922 , on the basis of gas furnished, was $\$ 2,346,357.18$. For the year ending Dec. 31, 1923, the return was $\$ 4,072,181.08$. The master, hovfever, said:

"I find that 8 per cent. is a rate customarily required in the locality to be earned on the present value of the property of a regulated public utility, and that the plaintiff should be permitted to earn at least this amount." Ibid. 274.

Since the company had not earned even $6 \%$, obviously there was no necessity for going into any $8 \%$ rate. Winslow, J., affirmed the master's finding as to the facts and went on to say:

"The return should be reasonably sufficient to assure corfidence in the financial soundness of the utility and should be adequate, under eficient and economical management, to maintain and support its credit and enable it to raise the money necessary for the proper discharge of its public duties." Ibid. 280.

Southwestern Bell Telephone Co. v. City of Ft. Smith, 294 Fed. 102 (W. D. Ark. 1923), aff'd, 270 U. S. 627, 46 Sup. Ct. 206 (1926). The main point determined in this case is whether or not going value is a proper element to be considered in making rates for telephone service. The District Court held that it was. All that is said with regard to the rate of return is as follows:

"By allowing a valuation of $\$ 685,605$, which includes a going value of 10 per cent, and by reducing the annual depreciation to 4 per cent., the city shows a return of 6.29 per cent. Its engineer admits that a fair return would be 8 per cent." Ibid. 108.

The preliminary injunction to restrain putting into efrect the ordinance rates was made permanent. There was no discussion as to whether the $8 \%$ was to be an over-all rate and it is quite clear that there was no evidence taken upon this point, since the city's own engineer was prepared to admit 
that a fair return would be $8 \%$. Analysis of the record might easily sustain the engineer's opinion on the history of this particular company.

Adirondack Power \& Light Corp. v. Public Service Comm., 211 App. Div. 272, 207 N. Y. Supp. 284 (3d Dep't 1925). The order in the case was annulled and the case sent back to the Public Service Commission for further determination. On the rate phase of the case the court said:

"Commissioner Semple has demonstrated in his opinion that a one dollar and seventy-five cent rate will produce an eight per cent return on the rate base of three hundred and seventy thousand dollars. We are given to understand that the one dollar and seventy cent rate allowed by the majority will, on that basis, produce not to exceed seven and one-tenth per cent return. Even assuming the rate base adopted as fair and that the ono dollar and seventy cent rate will yield to the company the amount for annual depreciation reserve allowed in Commissioner Semple's opinion and seven and one-tenth per cent return on that rate base, we think such rato of return under the circumstances of this case may well be considered inadequate, in view of the holding of the United States Supreme Court in Bluefield Waterworks \& Improv. Co. v. Public Service Comm. (supra). In that case the United States Supreme Court referred to the fact that the company had received a rate of return that was very low through $a$ long period up to the time of the inquiry by the Commission and that such fact should be taken into consideration and a higher rate allowed in order to be fair." Ibid. 275.

New York \& Queens Gas Co. v. Prendergast, 1 F. (2d) 351 (S. D. N. Y. 1924). All that the special master said under the heading "Rate of Return" pras:

"The plaintiff presented evidence by testimony of witnesses as to the rate of return which a public utility company such as the plaintiff should earn on the amount required to build or buy its property. They placed this at 10 per cent. The courts have found, at different times and under varying conditions, rates of return ranging generally from 6 to 8 per cont. [Citing cases already considered]. I believe, under the evidence and the decisions, the plaintiff might properly claim a return of 8 per cent. on the present value of its property used and useful for the benefit of the public. On no possible basis could it be found that it could earn, in view of $\mathrm{my}$ previous holdings, anything approximating this amount. But the question is not decisive in this case whether any given rate of return is or is not confiscatory, in view of my findings as to the results of operation." Ibid. 370 .

The court said:

"In the instant case the overwhelming proof is to the effect that the statutory rate would not even cover operating charges, let alone the question of sufficient revenue to approximate a reasonable return on its investment whether that investment be considered either upon the theory of original cost or present value conditions." Ibid. 374.

People's Gas \& Electric Co. v. Public Service Comm., 214 App. Div. 108, 211 N. Y. Supp. 662 (3d Dep't 1925), is devoted entirely to the consideration of the error of the Public Service Commission in failing to consider reproduction value and going value. No consideration was given to the percentage of return that should be earned.

Kings County Lighting Co. v. Prendergast, 7 F. (2d) 192 (E. D. N. Y. 1925 ). While the $8 \%$ rate is mentioned in the syllabus as "a reasonable rato of return for a gas company," the master found a rate base of $\$ 11,200,656$, upon which the returns estimated would provide only $2.94 \%$. There was testimony in the case by a witness that at least $8 \%$ was required "in order to maintain and support its [the company's] credit and to enable it to so cure new capital in competition with the requirements for capital." The Circuit Court of Appeals referred to the fact that the master had suggested as a reasonable rate of return not less than $8 \%$ : 
"But the master's report deals with present fair values. Of cource, if, when the new rate is fixed, values have changed, the Public Service Commission may make such new rate based upon evidence, and will be wholly unhampered by the findings or recommendations of the master." Ibid. 218 .

Brooklyn Union Gas Co. v. Prendergast, 7 F. (2d) 628 (E. D. N. T. 1925). In this case, resolving every doubt against the plaintiff, the court found that it was doubtrul "whether in any view of the situation the yield would be sufficient to meet the recurring payments of interest apon outstanding bonds." The plaintif introduced expert evidence which showed that a rate of $8 \%$ was a normal rate "in view of all the contingencies surrounding a business of this character." The court said:

"This seems in accord with prevailing conditions of which the court will take judicial notice, and seems also to be in harmony with current adjudications." Ibid. 654 .

The defendants did not offer any evidence upon this phase of the matter.

Southern Bell Tel. \& Tel. Co. v. Railroad Comm., 5 F. (2d) 77 (E. D. S. C. 1925). The special master found that the legislative rates which were enjoined yielded, on investment cost of $\$ 6,025,090.70$, not more than 2.47\%. No evidence vras offered in the case by either party regarding the capitalization or bond issues of the company. The court did not adopt tho $8 \%$ ruling of the master. It contented itself with finding that the rates were clearly confiscatory, saying:

"Indeed, the present value of the property as ascertained by the master and found by this court might be largely reduced and still those rates, based upon such reduced value, would not provide anything lilie a proper remuneration under the Constitution. . . The prescribed rates, in any possible view that could be taken of the value of the property, are unreasonable and confiscatory." Ibich. 98.

In Landon v. Court of Industrial Relations, 269 Fed. 433 (D. Knn. 1920), the court found a valuation of $\$ 2,500,000$. For the year ending Dec. 31 , 1920 , the company showed net earnings on the 80 cent gas rate approved by the Commission to be $\$ 34,794$. The court said that an $8 \% 0$ return would require $\$ 200,000$ a.year, a $6 \%$ return would require $\$ 150,000$ a year and a $4 \%$ return would be $\$ 100,000$ a year, which was more than the company could earn on the 80 cent rate as found by the court.

In Mobile Gas Co. v. Patterson, 293 Fed. 208 (D. Ala. 1923), it appeared that the dividends declared by the company during the entire 17 years of its operations aggregated only about $\$ 80,000$ and no dividends had been declared since December 31, 1917. From the order of the Commission itself it appeared that at the low rate then fixed, the company was not able even to meet its actual operating expenses. The net income for 1922, upon a basis of the rate enjoined, would have amounted to $\$ 91,963.93$, or $4.59 \%$ on a two million dollar investment. Setting up a depreciation and reserve of $2.5 \%$ on $\$ 2,000,000$, or $\$ 50,000$, its net earnings would be reluced to $\$ 41,963$, which the court says "is 2.09 per cent. upon a valuntion of $\$ 2,000$,000 and a less per cent. when going concern value is added." Clayton, J., did say, however (though unnecessary to his decision):

"I find that the plaintiff is entitled to earn 8 per cent. per annum upon the value of its used and useful property. This is the legal rate of interest in Alabama and in the absence of contract is presumed to be reaconable in the ordinary dealings between men, and by analogg chould be adoptce the evidence clearly establishes that in this case it does not excecd a fair return." Ibid. 221. 
New York Telephone Co. v. Prendergast, 300 Fed. 822 (S. D. N. Y. 1924). Here error was committed in the failure of the commission to include in the rate base going value. The court found that it had erred in the determination of the rate base, but in the course of its remarks it said:

"Admittedly it is and has been customary to allow as a reasonable rato of return for regulated businesses like this one, 8 per cent. The justification for the custom is the habit of business men, and a departure therefrom is not right because a court or commission prefers a lower rate. Reasons aro wanted, and none are set forth in this record. Under such circumstances there is no presumption of correctness attaching to the 7 per cent. limit. The question always raised in rate cases is this: What rate of return, with due regard to certainty and security, will attract the intelligent investor? It remains to be seen whether a departure from the present customary rato is warranted by modern conditions." Ibid. 826 .

There is hardly anything in this utterance, though it comes from very respectable sources, upon which the court is bound irrevocably to an $8 \%$ over-all standard. The decision was rendered in 1924. Since that time tho Pacific case has been decided. The technique for presenting evidence in the Pacific case was not resorted to in the Telephone Company case. "Reasons are wanted, and none are set forth in this record," said the court.

City of Minneapolis v. Rand, 285 Fed. 818 (D. Minn. 1923). Here the master fixed a gas rate based upon an assumed rate of return of $71 / 2 \%$ on the value of the property. This was challenged by the city as excessive. The court said:

"It is said that the company's bonds draw less interest, and therefore the stockholders will obtain more than $71 / 2$ per cent. in dividends upon their stock. It is obvious that this argament would not be of force, if the company were free from debt. It may be that the bonds of the company wore sold at a discount; but, if the company had the good fortune to goll its bonds at less than this rate of interest, that fact should not diminish the rate of return on the total value of the company's property. Neither could more than a fair return be demanded, if the company had the misfortune to be compelled to pay more than $7 / 2$ per cent. for money borrowed. The only testimony as to the local rate of returns required for such investments at Minneapolis at that time shows that 8 per cent. would be required." Ibid. 830.

This is the first and only case in those we have reviewed in which the court has said anything to indicate that the rate at which a company may borrow upon its bonds is not to be considered in determining the over-all rate. The reasoning of the court is not persuasive. It says, if the company were free from debt, the argument would not be of force. But this loses sight of the tests for determining the reasonableness of the rate stated so frequently by the United States Supreme Court. Moreover, this decision was rendered in 1923, before the decision in the Pacific case. 